\title{
＜シンポジウム：特異な原因による老年者の脳卒中＞
}

\section{1. 多血症和よび血小板血症}

\section{秋口一郎 塩 栄夫鈴木 元 亀山 正邦}

\begin{abstract}
＜要 旨＞ 1）真性多血症は全脳卒中の $0.4 \sim 1.0 \%$ 占め, 頭痛, 四肢動静脈血栓, 脾腫を合併する例 が多かった. 本態性血小板血症は全脳卒中の $0.5 \sim 1.1 \%$ 占め, TIA, 胃潰瘍, 心筋梗塞を合併する例が 多かった．特に胃潰瘍の合併は高率であり, 本症の初期診断と治療に重要と考兄られた。真性多血症で は CT 上, 脳卒中の各型が出現するが, 本態性血小板血症では TIA や皮質枝型脳梗塞が高頻度であった. 血小板凝集能は両者とも著明なえ進を示した。

2）二次性多血症を伴う脳卒中では脳梗塞，特に穿通枝型多発梗塞を高頻度に認めたが，血小板凝集能 はむしろ正常ないし軽度光進に留まった，軽度血小板増多症を伴う脳卒中では皮質枝型掞よび穿通枝型 梗塞を高頻度に認め，血小板凝集能は㐫進を示した。また，血小板血症の局所脳血流は，病巣以外は正 常域であった。

3）真性多血症, 本態性血小板血症では高度の血小板凝集能え進を示す例が多く, 個々の血小板機能が 低下していても各種の脳卒中の危険因子となりらる。特に本態性血小板血症では血流中で凝集塊が形成 されやすく，このことと TIA や境界領域型ないし皮質枝型梗塞が高頻度であることとの間に，何らかの 関連が考兄られる. 本症では，一般に，1 日 $0.08 \mathrm{~g} \sim 0.33 \mathrm{~g}$ の少量の aspirin で著明な凝集能抑制効果が みられたが，効果持続の短い例もあり投与法に留意する必要があった。
\end{abstract}

Key words：真性多血症，本態性血小板血症，血小板凝集能，脳梗塞，局所脳血流量

\section{緒 言}

本研究では, 中高年発症の脳血管障害に扔ける多血 症，すなわち，真性多血症打よび二次性多血症と血小 板血症，すなわち，本態性血症板血症掞よび血小板増 多症について，まずその頻度, 臨床症候の特徵, CT 所 見を検討した。次に血小板凝集能の特徵と実際の症例 に打ける治療経過を示し, 最後に脳血行動態, 脳循環 からみた多血症と血小板血症の特徵を検討した。

\section{方法}

（1）真性多血症，本態性血小板血症の診断は, Wintrobe ら, Thomas, Ginsberg, 山本ら, Jabaily ら の診断基準を参考にした ${ }^{11 \sim 5)}$. 二次性多血症はへマト クリット值が $50 \%$ 以上の症例，血症板増多症は血小板 数が 40 万 $/ \mathrm{mm}^{3}$ 以上の症例とし，それぞれ複数の施設 に打ける脳血管障害患者群より抽出した.

（2）CT 所見は，著者らの作成した脳梗塞 CT 分類 により評価・分類した ${ }^{6)}$ 。すなわち，（I）皮質枝型梗

I. Akiguchi, H. Shio, G. Suzuki, M. Kameyama : 京 都大学医学部神経内科
塞, (II) 穿通枝型梗塞, (III) 多発梗塞, (IV) 脳萎縮・ 傍脳室部低吸収像 (PVL), ( V ) 脳幹・小脳梗塞の 5 群である。なお皮質枝型のらち主幹動脈閉塞例では, 他に小梗塞を伴っていても多発梗塞とせず，皮質枝型 梗塞に分類した。一部の症例で $\mathrm{Xe}^{133}$ 吸入法により局 所脳血流を測定した。

（3）血小板凝集能については，aggregometerによ る ADP 凝集を, その二次凝集の有無により III型に分 け，仮に I 型を正常域，II型を軽度穴進型，III型をえ 進型として分類した ${ }^{7)}$.

\section{成績および考察}

\section{a）頻度}

真性多血症の頻度は0.4 1\%, 二次性多血症の頻度 は2.6〜 $3 \%$ であった. 真性多血症の 4 例はすべて, 血 小板増多症を伴っていた。一方, 本態性血小板血症は 0.5 1.1\%であり, すべて血小板数は 100 万 $/ \mathrm{mm}^{3}$ 以上 であった。血小板増多症は測定法の差やデータのバラ ツキから正確な頻度の算出は困難であったが， 2 施設 でそれぞれ約 $4 \%$ の頻度を示した（表 1 ）。

b）臨床症候

初期診断に有用之思われる症候・背景疾患を検討し 
表 1 脳血管障害に拈ける多血症・血小板血症の頻度

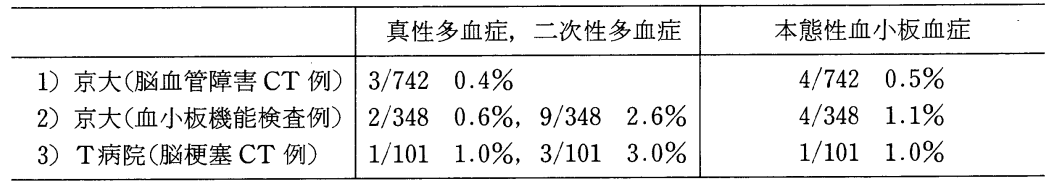

註：1)および2)の症例には重複がある。

表 2

Polycythemia vera

\begin{tabular}{l|c|c|c|l|l|l}
\hline No. & Case & Ht & Platelet & \multicolumn{2}{|c}{ Symptoms and Signs } & Therapy \\
\hline 1) & S S, 75M & 58 & $133 \times 10^{4}$ & $\begin{array}{l}\text { hemianopsia, } \\
\text { headache, } \\
\text { splenomegaly }\end{array}$ & $\begin{array}{l}\text { alexia with } \\
\text { agraphia, } \\
\text { dyscalculia }\end{array}$ & $\begin{array}{l}\text { venesection, } \\
\text { aspirin }\end{array}$ \\
\hline 2) & YM, 51M & 68 & $39 \times 10^{4}$ & $\begin{array}{l}\text { headache, } \\
\text { hypertension, } \\
\text { thrombosis, } \\
\text { splenomegaly }\end{array}$ & $\begin{array}{l}\text { TIA-IC, } \\
\text { hemiparesis, } \\
\text { Gerstmann } \\
\text { syndrome }\end{array}$ & venesection, \\
heparin
\end{tabular}

Essential thrombocythemia

\begin{tabular}{l|c|c|c|l|l|l}
\hline No. & Case & Ht & Platelet & \multicolumn{2}{|c|}{ Symptoms and Signs } & \multicolumn{1}{|c}{ Therapy } \\
\hline 5) & S M, 63 F & 31 & $151 \times 10^{4}$ & $\begin{array}{l}\text { hypertension, } \\
\text { carotid } \\
\text { aneurysm }\end{array}$ & $\begin{array}{l}\text { TIA-IC, } \\
\text { amaurosis fugax }\end{array}$ & $\begin{array}{l}\text { aspirin, } \\
\text { busulfan }\end{array}$ \\
\hline 6) & T D, 74M & 51 & $119 \times 10^{4}$ & $\begin{array}{l}\text { hypertension, } \\
\text { ulcus vent, } \\
\text { myocardial inf, }\end{array}$ & $\begin{array}{l}\text { TIA-IC, } \\
\text { Gerstmann synd, } \\
\text { hemiparesis }\end{array}$ & $\begin{array}{l}\text { aspirin, } \\
\text { dipyridamole }\end{array}$ \\
\hline 7) & MU, 71M & 37 & $156 \times 10^{4}$ & $\begin{array}{l}\text { ulcus duod, } \\
\text { headache, } \\
\text { subdural } \\
\text { hematoma }\end{array}$ & $\begin{array}{l}\text { amnesia, } \\
\text { disorientation }\end{array}$ & $\begin{array}{l}\text { aspirin, } \\
\text { dipyridamole }\end{array}$ \\
\hline 8) & T K, 69F & 20 & $212 \times 10^{4}$ & $\begin{array}{l}\text { ulcus vent } \\
\text { frontal lobe } \\
\text { sign, rigidity, }\end{array}$ & $\begin{array}{l}\text { aspirin, } \\
\text { dipyridamole }\end{array}$ \\
\hline 9) & H K, 39M & 25 & $105 \times 10^{4}$ & $\begin{array}{l}\text { ulcus vent, } \\
\text { myocardial inf, } \\
\text { focal glomerulo- } \\
\text { sclerosis }\end{array}$ & TIA-VA & $\begin{array}{l}\text { aspirin, } \\
\text { dipyridamole }\end{array}$ \\
\hline 10)* & T O, 67 F & 37 & $80 \times 10^{4}$ & $\begin{array}{l}\text { hypertension } \\
\text { hemiparesis }\end{array}$ & aspirin \\
\hline
\end{tabular}

${ }^{*}$ secondary thrombocytosis

た ${ }^{8) ~ 12)}$. 真性多血症は表 2 に示したように 4 例みとめ た(表 2 ). 初発ないし経過中の主要症候として頭痛を 4 例中 3 例, 脾腫を 3 例, 高血圧を 2 例に認め, 2 例 で反復する動脈ないし静脈血栓を認めた。古德らによ る真性多血症例の統計によれば，やはり頭痛が初診時 神経症候の半数を占め, 脳卒中発作を初発症候とする 例も $29 \%$ に認めている ${ }^{8)}$. 本症では頭痛, 動静脈血栓, 脳卒中発作の既往に十分留意する必要がある。
本態性血小板血症は 5 例認めた. 症候上の特徵とし て, 比較的難治性の胃ないし十二指腸潰瘍を 5 例中 4 例, 一過性脳虚血発作 TIA 3 例 ( らち一過性視力喪 失 amaurosis fugax 1 例), 心筋梗塞, 高血圧を各 2 例に認め, 腎の細動脈病変である focal glomerulosclerosisを 1 例に認めた. Jabaily らは神経症候として はやはり頭痛と視力障害が高頻度であり, 視力障害で は一過性視力喪失 amaurosis fugax が特に高頻度に 
多血症の CT 所見

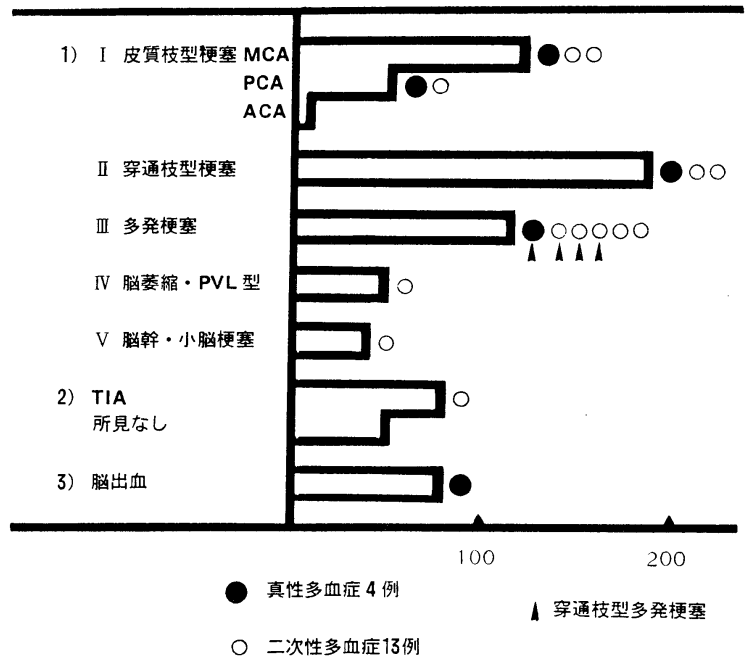

a)
血小板血症の CT 所見

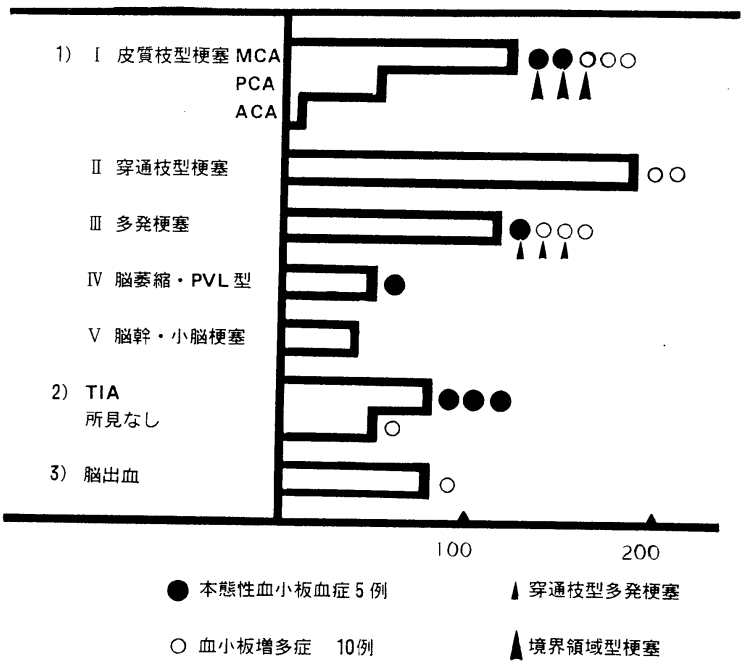

b)

図 $\quad 1$

認められることを示している5). 本症では胃・十二指腸 潰瘍, 頭蓋外血管病変, 一過性視力圱失の合併に留意 する必要がある。特に胃・十二指腸潰瘍の合併は従来 あまり記載がない，本症が aspirin 治療を必要とする 場合が多いことからも本症の初期診断, 初期治療の問 題点として特に重要である.

C) CT 所見

図 1 a)b)の棒グラフは, 著者らによる脳梗塞 CT 分 類により, 脳血管障害自験742例の分類別頻度を示した ものである(図 1). この頻度分布の上に図 1 a)で多血 症のCT所見をプロットした。黒丸が真性多血症の 4

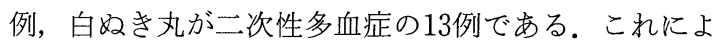
れば全脳血管障害742例の分布と較べ, 真性多血症では 各型に分散するが, 二次性多血症では多発梗塞, 特に 穿通枝型の多発梗塞を高頻度に認める点が特異であっ た。

図1b)に同様にして血小板血症の CT 所見を示し

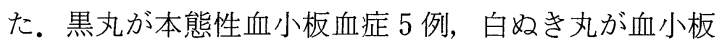
増多症10例である. この場合は, 皮質枝型梗塞, 特に 境界領域型梗塞と TIA 多く認める点が特異であっ た。

d）血小板凝集能

図 2 a)で血小板血症10例, 多血症11例, 脳梗塞268例 の凝集能パターンを示した。多血症では，真性多血症 の 1 例が亢進型（III型：9\%) であるのを除き，他は すべて正常域 (I 型：27\%) ないし軽度六進型（II 型：
64\%)を示した。この所見は全脳梗塞で正常域(37\%)， 軽度亢進型 $(40 \%)$, 六進型 $(23 \%)$ であったのと較べ て,むしろ亩進型が少ないといら傾向を示して扣り， 多血症時の他のリスク要因である血小板凝集能の動向 として興味深い. 一方, 血小板増多症では全例で凝集 能元進を認めた。すなおち正常域はなく, 軽度克進型 が22\%で，六進型が78\%であった。図の星印は本態性 血小板血症，真性多血症をそれぞれ示している。

図 2 b) は脳梗塞 CT 分類に対応させた左, 多血症, 右, 全脳梗塞268例の凝集能パターンである.多血症で は穿通枝型多発梗塞を多く認めるが，梗塞型と凝集能 パターンとの間に関連はない. 前述のように全体とし て凝集能は, 正常ないし軽度六進に留末っている.

図 2 c) は血小板血症之脳梗塞の凝集能パターンで ある. 血小板血症では皮質枝型梗塞と多発梗塞を多く 認め, 皮質枝型では全例が立進パターンを示した。

e）治療

つぎに症例を呈示し，治療の問題点を示すことにす る.

〔症例 1〕75歳男, 血小板増多症を伴う真性多血症 の症例である(表 2).1981年 1 月21日，外出より帰宅 後, 呕気, 呕吐あり。1月23日, 左前頭から頭頂部痛, 右視野障害が出現した。 入院時には失書失読，失算， 右同名半盲, 脾腫を認めた。意識は清明，血圧は140/ 60 であった。血液所見は Ht57.5\%, Hb $18.2 \mathrm{~g} / \mathrm{d} l, \mathrm{RBC}$ 692 万 $/ \mathrm{mm}^{3}$, 赤血球容積 $46.8 \mathrm{ml} / \mathrm{kg}, \mathrm{O}_{2}$ 飽和度 $95 \%$, 


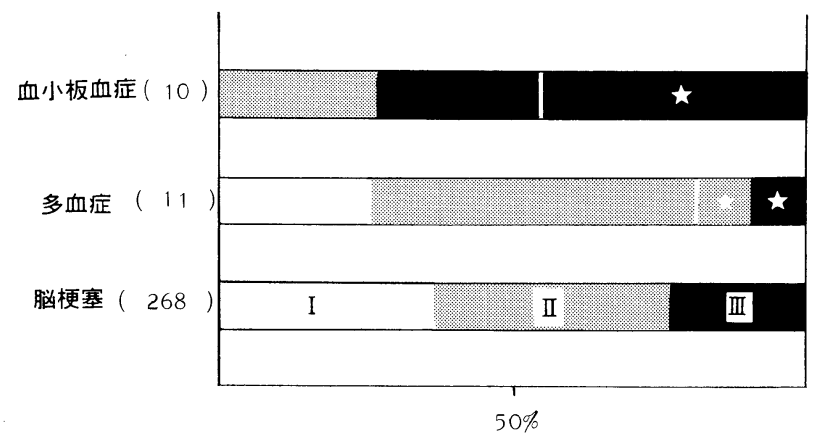

a)

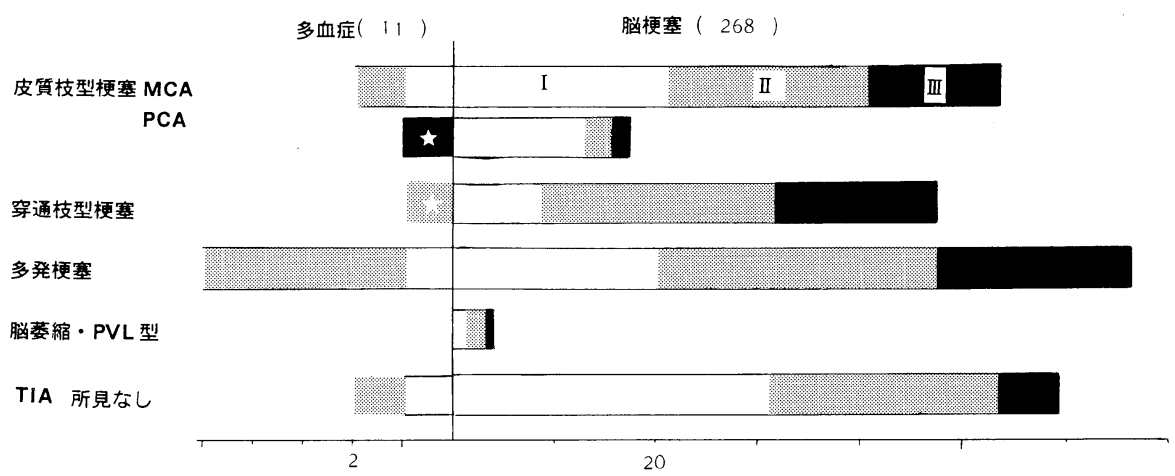

b)

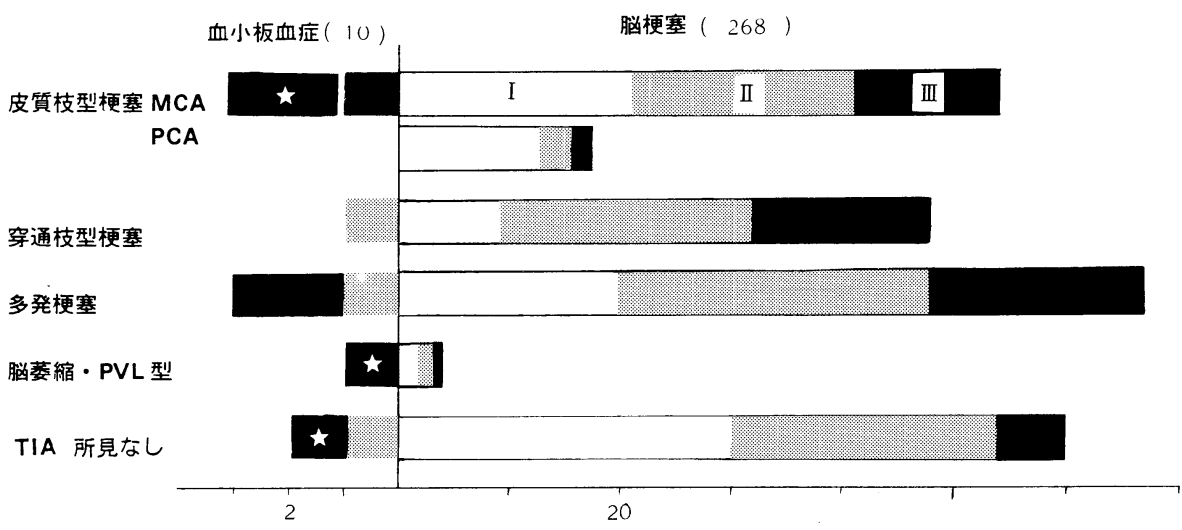

c)

図 2

$\mathrm{VB}_{12} 1,150 \mathrm{pg} / \mathrm{m} l, \mathrm{NAP}$ score 正常域, 白血球14,200, 血小板 133 万 $/ \mathrm{mm}^{3}$ であった。骨髄所見で赤血球，巨核 球系過形成を認めた。CT では左後頭葉に出血性梗塞 を認めた。

入院後泻血を行ったが, 血小板数が増加し, 血小板 機能が ADP 凝集で亢進パターンを示したため, aspirin $0.66 \mathrm{~g} /$ day を投与した。 その後，凝集能は低下し，
以後症状の悪化，新たな症候の出現はない.

[症例 5]63歳女性. 本態性血小板血症の症例であ る. 1979年 8 月頃より一過性に右上肢の筋力低下, 言 語障害発作を頻発するようになった。1980年 1 月，右 上下肢筋力低下とともに，計算障害が出現し，8月に は書字困難が加わった。1981年 5 月の京大病院入院時 には, Gerstmann 症候，右上下肢不全麻痺を認めた。 
意識は清明, 血圧は180/102であった. 血液所見は, Ht が $31 \%, \mathrm{Hb} 10.6 \mathrm{~g} / \mathrm{d} l, \mathrm{RBC} 384$ 万 $/ \mathrm{mm}^{3}$, 白血球 4,900 , 血小板は 77 万 $/ \mathrm{mm}^{3}$ であった。骨䯣所見では巨核球の 著明な増殖を認めたが NAP scoreなどは正常域で あった，CTでは，左角回に低吸収域を認めた。

入院後, 一過性視力喪失が出現し, ADP による血小 板凝集能が亢進型を示したので, aspirin $0.33 \mathrm{~g} /$ day 使用した。 その後血小板凝集能は低下, 以後症状の増 悪はない。経過中に血小板数が 150 万 $/ \mathrm{mm}^{3}$ まで達した ため, busulfan $2 \mathrm{mg} /$ day を併用した。

〔症例 6] 74歳男. 本態性血小板血症の症例である. タバコ好きで, 既応に胃・十二指腸潰瘍, 高血圧があ る. 1979年 9 月頃より, 数分間持続する左上肢の脱力 発作があり, TIA の診断で京大病院に入院した. 入院 時, 意識清明, 血圧 $154 / 90$, 神経学的には軽度の左上 下肢脱力を認め, 血液所見は, 血小板 119 万 $/ \mathrm{mm}^{3}, \mathrm{Ht}$ $51 \%, \mathrm{Hb} 17.8 \mathrm{~g} / \mathrm{d} l$, 赤血球 610 万 $/ \mathrm{mm}^{3}$, 白血球 10,100 であった。 erythropoietin, NAP score, $\mathrm{VB}_{12}$ などは正 常域であった。

血小板機能は，ADP 凝集が亢進パターンを示した。 aspirin $0.33 \sim 0.66 \mathrm{~g} /$ day 投与にて凝集能は低下し, TIA は著明に減少したが, 胃潰瘍よりの出血のため投 与を中止せざるを得なくなった。 中止後, 右上肢脱力 発作を頻発するようになり, dipyridamole を投与した が, 1981年 7 月, Gerstmann 症候が急に出現し, CT に より左角回の低吸収域を認めた。10月にはさらに右上 下肢脱力, 意識障害が出現し, CT では左側脳室前角よ り左前頭葉にかけて境界領域型の低吸収域が出現し た。その間, dipyridamole, ticlopidine を投与してい るが，血小板凝集能の亢進パターンの抑制はみられて いない.1982年 5 月, 心筋梗塞が出現し, 凝集能進 パターンが持続するため, 抗潰瘍剤との併用で aspirin $80 \mathrm{mg}$ 錠の一日 2 回投与を再開した. 凝集能パターン の追跡では aspirin 80mg一日 1 回では光進型を示す ため, $160 \mathrm{mg} /$ day を維持量とし, 以後 control は良好 である。

血小板増多症, 特に本態性血小板血症では, 循環凝 集血小板, 血小板自然凝集は㠵進しているが, 粘着能, $\mathrm{ADP}$, エピネフリン凝集等はむしろ低下例のあること が報告されている. 我々の示した血小板血症の 2 症例 （症例 5,6 ）之血小板増多症の 2 症例（症例 1,10 ) ではADP 凝集を指標した凝集能はいづれも六進パ ターンを示した。一方, エピネフリン凝集に関しては 症例 1,5 のみが感受性を示し，エピネフリン凝集に
関しては一様ではなかった。

治療に関しては, 全例に aspirin を用い, 症例 1 には 泻血，症例 5 にはブスルファンを併用したが，いづれ も投与後, 血小板凝集能低下がみられ, aspirin 投与中 は, TIA, amaurosis fugax の減少又は消失があり, 新 たな症状の出現もなかった。症例 6 では胃潰瘍再発の ため投与中止後, 血小板凝集能の六進, 脳虚血発作の 再発がみられ, aspirin 投与中止との相互関係が示唆さ れた。

\section{f）脳循環, 脳血行動態}

著者らが検討した本態性血小板血症 2 例, 血小板増 多症 1 例に怙ける $\mathrm{Xe}^{133}$ 吸入法による局所脳血流量 （rCBF）を左右半球別の mean ISI 值で示寸.

[症例 5 〕 63歳女性. 血小板 151 万, $\mathrm{Ht} 31 \%$, 血小板 凝集能は元進型である(表 2 ). 左脳梗塞に対応して左 は $43 \mathrm{~m} l / 100 \mathrm{~g} / \mathrm{min}$ (正常 $52(38 \sim 65) \mathrm{m} l / 100 \mathrm{~g} / \mathrm{min}$ ) とやや低值であるが, 右は $50 \mathrm{~m} l / 100 \mathrm{~g} / \mathrm{min}$ と正常域で あった。

〔症例 9〕 39歳男性. 血小板 105 万, Ht $25 \%$, 血小 板凝集能は亢進型である。椎骨脳底動脈系の TIA を認 めたが, $\mathrm{rCBF}$ は左 80 , 右 $81 \mathrm{~m} l / 100 \mathrm{~g} / \mathrm{min}$ と高值を示 し, むしろ貧血による $\mathrm{rCBF}$ の増加が示された。

〔症例10] 67歳女性, 血小板 80 万, Ht $37 \%$, 血小板 凝集能六進型の血小板増多症の症例である。CT では 左皮質枝型脳梗塞を認めたが, $\mathrm{rCBF}$ は左 63 , 右 $65 \mathrm{~m} l /$ $100 \mathrm{~g} / \mathrm{min}$ と正常であった。

上記 3 症例の $\mathrm{rCBF}$ は血小板凝集能の著明な元進 にもかかわらず，虚血病巣をのぞき全般に正常域を示 した。すなわち血小板増多はそれのみでは脳血流に影 響を与えないことが指摘された。一方，本症では TIA と皮質枝型梗塞, 特に境界領域型梗塞を多く認め, TIA が抗血小板薬で著明に抑制された。一般に，境界領域 型梗塞では，その成因として低環流圧の episode のみ でなく, microemboli, 血小板凝集能異常の関与が考兄 られている ${ }^{17)}$.また本症では血小板自然凝集が充進し, 流血中で凝集塊が形成されやすいことも報告されてい る ${ }^{15)}$. したがってこれらの塞栓易形成傾向と本症で TIA，境界領域梗塞が好発することとの間に，何らかの 関係があるものと考兄られる。

一方, 多血症でみられる高 $\mathrm{Ht}$ 值, 高 $\mathrm{Hg}$ 血症は血行 力学的にみた脳卒中のリスク要因であり, plasma skimming などとの関連において，特に穿通枝型梗塞 など小動脈領域病変でのリスク要因でもある(13) 16). こ の意味に扮いて本研究の二次性多血症例で穿通枝型多 
発梗塞が高頻度であった点は注目される。ぬた, 血液 $\mathrm{Hg}$ 濃度が70\%以下になると脳血流が有意に上昇する こと, $\mathrm{Ht}$ 值を平均 $53 \%$ から $44 \%$ まで招とすと血液粘度 が30\%低下し，脳血流が73\%増加することなどが明ら かにされている13144. したがって多血症では hemodilusion therapy が必要でめり, 特に老年者, 心 不全・腎不全患者では，泻血分を低分子デキストラン で補充する normovolemic hemodilusion が有効と考 えられる ${ }^{13)}$.この点に関し Gottstein は, 多血症患者の 脳血管障害では, $1 l$ の dextran 40 と $1 l$ の維持カクテ ル液を一日投与量とし, 同時に毎日 $300 \mathrm{~m} l$ の泻血を行 ない，7〜14日間の治療で Ht を最終的に $40 \%$ 以下に するといら方法をすすめている ${ }^{13)}$. 本研究ではこの点 に関し,成績を示すことはでさなかったが, 今後中高年 の多血症患者に扮ける normovolemic hemodilusion therapy の検討が望まれる。

\section{文 献}

1) Wintrobe MM, Lee CR, Boggs DR, Blthell TC, Foerster J, Athens JW, Lukens JN: Thrombocytosis, polycythemia vera. In: Clinical Hematology, Lee \& Febiger, Philadelphia, 1128 -1134, 1596-1614, 1981.

2) Thomas DF ; Haematological aspects of cerebral arterial disease. In: Vascular Disease of the Central Nervous System. Ross Russell RW (ed), Churchill Livingstone, Edinburgh, 337 $-355,1983$.

3) Ginsburg $\mathrm{AD}$ : Platelet function in patients with high platelet counts. Ann Intern Med 82 : 506-511, 1975.

4）山本富一, 大熊 稔, 右京成夫, 内野治人：原発性 血小板血症一本邦報告例 (32例) の検討。臨床血液 $20: 892-900,1979$.

5) Jabaily J, Iland HJ, Laszlo J, Massey EW, Faguet GB, Briere J, Landaw SA, Pisciotta AV : Neurologic manifestations of essential thrombocythemia. Ann Intern Med 99:
513-518, 1983.

6）秋口一郎, 相井平八郎, 亀山正邦：右同名半盲を伴 万急性発症の痴呆症候群。臨床神経学 21 ： 172-178, 1981.

7）塩 栄夫, 亀山正邦：血小板機能抑制効果. 脳神経 外科 $9: 113-122,1981$.

8）古徳利光, 川上倖司, 丹野慶紀 : 真性多血症之脳血 管障害. 臨床神経学 10：585-592，1970.

9）亀山正邦：各種疾患と脳血管障害. 日本臨床 $34: 97-104,1976$.

10) Millikan $\mathrm{CH}$, Siekert RG, Whisnant JP : Intermittent carotid and vertebral-basilar insufficiency associated with polycythemia. Neurology $10: 188,1960$.

11) Berg L: Hematologic and related system diseases. In: Merritt's Textbook of Neurology. Rowland LP (ed), Lea \& Febiger, Philadelphia, 688-690, 1984.

12）服部 晃, 長山礼三, 柴田 昭：血小板増多症一そ の抗血小板療法. 最新医学 $35: 2274-2281$, 1980.

13) Toole JF: Brain infarction. In: Cerebrovascular Disorders. Toole JF (ed), 3rd ed, Raven Press, New York, 214-230, 1984.

14) Schmid-Schönbein H: Macrorheology and microrheology of blood in cerebrovascular insufficiency. Eur Neurol 22, Suppl 1:2-22, 1983.

15) Preston FE, Martin JF, Stewart RM, DavisJones GAB: Thrombocytosis, circulating platelet aggregates, and neurological dysfunction. Br Med J 15 : 1561-1563, 1979.

16) Toole JF: Microcirculation and diseases that affect it. In: Cerebrovascular Disorders. Toole JF (ed), 3rd ed, Raven Press, New York, 327 $-336,1984$.

17) Torvik A: Pathogenesis of watershed infarcts in the brain. Stroke $15: 221-223,1984$ 
Abstract

\title{
Cerebrovascular Disease in Aged Patients with Polycythemia or Thrombocythemia
}

\author{
Ichiro Akiguchi, Hideo Shio, Gen Suzuki and Masakuni Kameyama
}

Clinical symptoms, computed tomography (CT) findings, platelet aggregability and regional cerebral blood flow (rCBF) were studied in aged patients having cerebrovascular diseases (CVD) with polycythemia or thrombocythemia.

Among three different groups of stroke patients from university or public hospitals, the frequency of polycythemia vera (PV) was $0.4-1.0 \%$, and that of essential thrombocythemia (ET) was $0.5-1.1 \%$, respectively.

Four patients with PV showed headache (3/4), splenomegaly (3/4) and arterial or venous thrombosis (2/4) before their admission for CVD care. Five patients with ET showed duodenal or gastric ulcer (4/5), transient ischemic attacks (TIAs) (3/4), and myocardial infarction $(2 / 4)$.

Temporal profile and CT findings of the PV group showed various patterns of stroke. Those of the ET group, however, specifically showed TIAs (3/5) and cerebral infarction of borderzone type (2/5). Platelet aggregability of both groups showed hyperaggregation pattern for ADP.

CT findings of 13 stroke patients with secondary polycythemia (patients showing Hematocrit values of over $50 \%$ ) specifically showed single or multiple infarctions of the perforating branch type (5/13). Platelet aggregability of those patients, however, showed a normal aggregation

Department of Neurology, Kyoto University School of Medicine pattern or, at most a hyperaggregation pattern of a mild degree. CT findings, of 10 stroke patients with secondary thrombocytosis (patients showing platelet couts of over 40 $\times 10^{4} / \mathrm{mm}^{3}$ ) preferentially showed both cortical and perforating branch type (3/10 and 4/10). Platelet aggregability showed a hyperaggregation pattern or a hyperaggregation pattern of a mild degree.

rCBF measurement using 133-Xe inhalation technique in three patients with thrombocythemia showed normal values except for the region of infarcts. In our stroke patients with essential thrombocythemia, there was a high frequency of TIAs and borderzone infarction. In addition, low doses of aspirin ( $0.08-0.33 \mathrm{gm}$./day) were effective for prevention of TIAs. As to major causes of borderzone infarction, not only the hypotension episode, but also frqgmentation of circulating emboli and familial hematogemous disorders with abnormal platelet aggregation were pointed out. Moreover, a high frequency of TIAs and cerebral infarcts due to spontaneous platelet aggregation and circulating platelet aggregates were reported among patients with thrombocythemia.

These reports may explain our results of the high frequency of TIAs and borderzone infarction and the therapeutic effect of aspirin in thrombocythemia. The role of hemodilution therapy in polycythemia is also discussed in this study.

key words: polycythemia vera, essential thrombocythemia, cerebral infarction, platelet aggregability, $r C B F$ measurement

(Jpn J Geriat 22: 93-99, 1985) 
〈シンポジウム：特異な原因による老年者の脳卒中＞

\title{
2. DIC
}

\section{山之内 博 名倉 博史 松田保}

\begin{abstract}
＜要 約 > 1972年 7 月より 1984年 3 月までの東京都養育院付属病院における連続剖検例 2,709 例中 375 例 (13.8\%) に凝血学的に明らかな DIC の発現がみられた。このうち60歳以上で, 髄膜炎, respiratory brain, 脳手術例を除外し，乙かも brain cutting を施行した304例を対象として，DIC の脳病理組織学的 病変と神経症状，血液所見などとの関連につき検索した。な利304例の DIC 例中，悪性腫瘍例は 158 例 (52.0\%), 重症感染症例は37例 (12.2\%)である。剖検により脳血管障害を認めない例は80例 (26.3\%), 陳旧性病変しか認められない例は112例 (36.8\%)であるが, 出血性梗塞を含む虚血性病変は68例 $(22.4 \%)$ に, 出血性病変, 虚血性病変の混在は23例 (7.6\%), 硬膜下血腫を含む出血性病変のみられる例は 21 例 (6.9\%)であった。な挔，虚血性病変としては，大梗塞，皮質梗塞多発など，比較的大きな病変が多かっ たが, 出血性病変は点状出血程度の小病変が大多数を占めた。 DIC 例の神経症状としては, 意識障害, 痉挛, 片麻瘏などが主なものであるが, 病理組織学的に脳病变のみられる例では, 神経症状の発現頻度 が高く, また片麻痺のみられる例が多かった。一方, 脳病変のみられない例では血液生化学的に代謝障 害のみられる例に神経症状の発現頻度が高かった, 脳底動脈硬化度, へマトクリット值と脳病変の性質, 頻度には差がなかったが，非細菌性血栓性心内膜炎（NBTE）または心房・心室の壁在血栓のみられる 例では大梗塞または皮質梗塞の頻度が高かった，以上，老年者の DICにおいては，種々の脳病変，神経 症状を伴らことが少なくなく, それは代謝障害, NBTEからの塞栓により修飾されるが, 動脈硬化度, 血液粘度とは無関係と思われた。
\end{abstract}

Key words：DIC，脳卒中，意識障害，痉挛，非細菌性血栓性心内膜炎

\section{I.はじめに}

DIC (disseminated intravascular coagulation, 播 種性血管内凝固）は，一種の極端な血栓傾向であり， 種々の原因によって全身の主として細小血管内に血栓 の多発を生ずる症候群であるが, 通常, 血栓の多発に より流血中の血小板やフィブリノゲンをはじめとする 凝固因子が血栓の材料として，また活性化後血中の阻 止因子が網内系によって処理されて低下し，その本態 は極端な血栓傾向であるのに，消費性凝固障害と呼ば れる特異な出血傾向がみられることが多い。このため, DIC では見かけ上血液の凝固性が低下し, 明らかに出 血症状がみられるのに, 血管内凝固発現を阻止する目 的で抗凝血薬であるへパリンが使用され，少量のへパ リン使用後, しばしば消費性凝固障害の改善, 出血傾 向の改善がみられる11.

当初, DIC 恃異な凝固異常として, 主として極端

H. Yamanouchi, H. Nakura：東京都養育院付属病院 神経内科

T. Matsuda：金沢大学第三内科
な出血傾向を呈する例が血液凝固学者によって注目さ れ，極めて珍らしい症候群と考兄られていた。しかし， DIC に関する知識の普及, FDP の測定の一般化に伴 い，DIC は決して当初考光られていたほどめずらしい ものではなく,ことに老年者に和ける DIC の発現頻度 は高く ${ }^{233}, \mathrm{DIC}$ に関する知識は老年者の診療に際して 不可欠と考兄られるに至った。

DIC の臨床症状としては, DIC の基礎疾患によるも の，DIC による血栓多発に基づくもの，消費性凝固障 害による出血性素因によるものなど多彩であり, 決し て当初考兄られたように出血性素因のみが重要なので はなく,ささざまの臟器症状がみられ2) 4), 従来, 死戦 期にみられる説明困難な症状として見逃されて来た症 状のうち，DICによって説明し得るものが少なくない と思われる。

本稿では，特異な原因による老年者の脳率中のひと つとして，DICによるものにつき述べることとする。

\section{II. 対 象}

1972年 7 月より1984年 3 月までの 11 年 8 カ月の間に 
東京都養育院付属病院に招いて剖検を行った連続 2,709 例中，主としてフィブリノーゲン量, 血小板数, FDP 量に, DIC の背景に存在する疾患を加味してスコ アリングを行う著者古の診断基準によってまず375例 (13.8\%)をDIC と判定した. 次いで, このうち60歳以 上で, 髄膜炎, respiratory brain, 脳手術例を除外し, しかも brain cutting を施行したもの304例を選び，こ れを対象として検索を行った。なお，304例の内訳は， 60 69歳36例, $70 \sim 79$ 歳137例, 80～89歳109例, 90歳 以上 21 例であるが，このうち悪性腫瘍は158例( $52 \%)$, 重症感染症は37例（12\%）を占めている。

\section{DIC 例の脳病変}

上記の 304 例中, 剖検により脳血管障害を認めない例 は80例 (26.3\%)，また陳旧性病変しか認められない例 は112例（36.8\%）であった。これに対し, 点状出血, 小梗塞を含む DIC と関連する可能性のある病変の認 められる例は112例 (36.8\%) であるが，このらち脳に 比較的新鮮な出血性梗塞を含む虚血性病変の認められ る例は68例 (22.4\%), 虚血性病変と出血性病変 (硬膜 下血腫 3 例を含む) の混在の認められる例は23例 (7.6\%), 出血性病変 (硬膜下血腫 1 例を含む) のみが 認められる例は 21 例 $(6.9 \%)$ であった。

このような脳に扣ける DIC 病変を, 病理組織学的に 病変が径 $5 \mathrm{~mm}$ 以下の小病変に限られるもの, 中等大病 変（分枝閉塞に相当する梗塞または非致死的出血）を 有するもの, 大病変（基幹部閉塞に相当する梗塞，皮 質梗塞多発または致死的出血）に分類し，病変の性質 と大きさの関係について検索した。 その結果，図 1 の ように虚血性病変では大病変が比較的多いのに対し， 出血性病変を呈する例では点状出血を認める例が大多 数を占めていた。

\section{DIC 例の神経症状と脳病変}

脳病変の有無のほかに, ショック, 低体温 $\left(36^{\circ} \mathrm{C}\right.$ 末 満), 血清蛋白 $4.5 \mathrm{~g} / \mathrm{d} l$ 未満, 血中尿素窒素 $90 \mathrm{mg} / \mathrm{d} l$ 以 上, $\mathrm{pO}_{2} 55 \mathrm{mmHg}$ 末満, 血液 $\mathrm{pH} 7.3$ 未満, 血清ナト リウム $160 \mathrm{mEq} / l$ 以上または $125 \mathrm{mEq} / l$ 末満, 血清カ ルシウ $7 \mathrm{mEq} / l$ または $3 \mathrm{mEq} / l$ 末満, 血清燐 $1.5 \mathrm{mg} /$ $\mathrm{d} l$ 末満, 血中アンモ $=ア 100 \mu \mathrm{g} / \mathrm{d} l$ 以上, 血糖值 $40 \mathrm{mg} /$ $\mathrm{d} l$ 未満の何れかの所見が同時にみられ，代謝または循 環障害が神経症状の発現に影響し得る可能性の考兄ら れる例の神経症状についても検索した。すず，DIC と 関連すると思われる脳病変の認められなかった例を上
記のような検査所見の有無より，代謝，循環障害があ ると考光られる例と，これを認めない例の 2 群に分け た。代謝・循環障害の認められる 100 例中, 神経症状の みられる例は 62 例 $(62 \%)$ であるが，代謝・循環障害 のみられない92例中神経症状のみられる例は31例 （34\%）で，代謝・循環障害のみられる例に有意（ $\mathrm{p}<$ 0.01) に神経症状の発現頻度が高かった。なお, 代謝・ 循環障害を認める例中, 神経症状のみられた 62 例中 42 例 $(68 \%)$ では意識障害の及がみられ，20例について は意識障害以外の神経症状もみられた。このうち12例 $(60 \%)$ には㾏挛が， 6 例には片麻瘒がみられた。残り の 2 例には, 瞳孔不同, 共同偏視などの症状がみられ ている。をた，代謝・循環障害を認めない例中，神経 症状のみられた 31 例中17例（54\%）は意識障害の及が みられたが，14例には意識障害以外の神経症状もみら れた。このらち10例 (71\%) は痉挛であり, 残りの 4 例には瞳孔不同，共同偏視などがみられた。なお，片 麻㿁を伴う例は 1 例のみで痉挛に合併してみられてい る。つまり, 病理組織学的に脳病変が認められない DIC の例では, 意識障害以外の症状としては㾏挛が重 要であるが，片麻痺は代謝・循環障害を伴う例の一部 にみられるのみである。

次に病理組織学的に脳病変のみられる例についてで あるが，同時に代謝・循環障害のみられる51例中43例 （84\%）に，ぬた代謝・循環障害の認められない61例中 45例 $(74 \%)$ に神経症状が認められた。脳病変の認め られない例の場合とは異なり，代謝・循環障害の有無 と神経症状の発現との間には有意の差はないが，脳病 変を有する場合が脳病変を有しない場合に比べ, 代 謝・循環障害の認められる場合も認められない場合も, 神経症状の発現頻度は有意 $(\mathrm{p}<0.01)$ に高くなってい る.なお, 代謝・循環障害を有し, 神経症状のみられ る43例中, 神経症状として意識障害の久がみられる例 は21例 (49\%) で, 残りの22例にはその他の症状の合 併がみられる。意識障害以外の症状としては, 痉挛 ( 6 例, $27 \%$ ), 片麻瘏 ( 7 例, $29 \%, 1$ 例は痉挛に合併) のほか, 10例 (46\%) 飞瞳孔不同, 共同偏視, 病的反 射などがみられている。な拈，代謝・循環障害のみら れない61例中, 神経症状のみられた45例については, らち 8 例が意識障害のみであり，37例に意識障害以外 の合併がみられた。このらち, 㾏挛は 5 例 (14\%), 片 麻疸は 20 例 ( $54 \%, 1$ 例は痉挛に合併), その他, 瞳孔 不同，共同偏視などは 13 例（36\%）にみられた。前述 の代謝・循環障害がなく, また病理組織学的に脳病変 

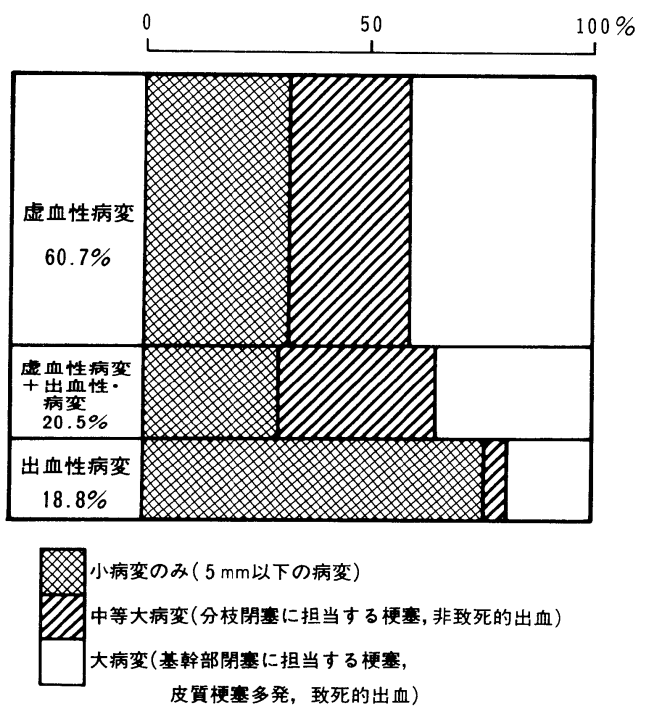

図 1 DIC 剖検例中，DIC に関連すると思われる脳病 変を有する112例における病変の種類と大ささの関 連

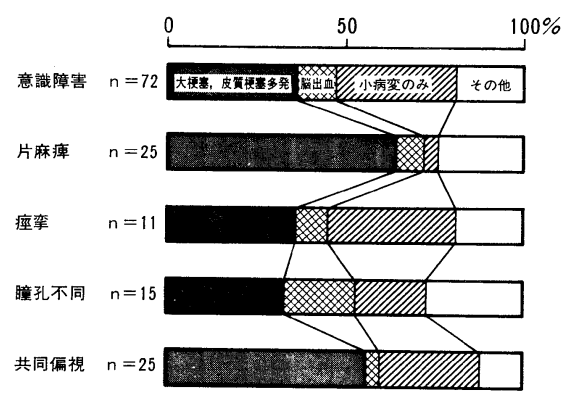

図 2 DIC に関連すると思われる脳病変を有する例 に扣ける神経症状と脳病理所見

を有していない例に比べ㾏挛の頻度が低いようである が，脳病変のない例に拈ける頻度 $(11 \%)$ と脳病変を 有する例のそれ (8\%) には大差はない。しかし，片 麻痺の発現頻度は前者が $1 \%$, 後者が $33 \%$ と明らかに 差がみられる $(\mathrm{p}<0.01)$ ，な招，脳病変のみられる例 につき意識障害, 片麻痺, 痉挛, 瞳孔不同, 共同偏視 などの神経症状と脳病変の性質につき図 2 に一括して 示したが，片麻痺のみられる例は大梗塞または皮質硬 塞の多発がみられる例が多いのに，小病変のみしか認 められない例は少ない、また，意識障害，疼挛のみら れる例は, 小病変のみみられる例が比較的多い上らで ある。

\section{V. 脳底動脈の硬化度と脳病変}

110例について検索を行ったが, 動脈硬化が比較的軽 度な29例中, 大梗塞采たは皮質梗塞多発のみられる例 は 9 例 (31\%), 脳出血は 3 例 $(10 \%)$, 小病変のみの 例は 12 例 (41\%)，その他 5 例 (18\%) である。一方, 動脈硬化が高度な例 81 例中, 大梗塞，皮質梗塞多発の みられるのは 22 例 (27\%), 脳出血 8 例 ( $9 \%$ ), 小病 変の久 33 例 $(41 \%)$, その他18例 (23\%) で, 動脈硬化 の有無と, 脳病変の性質との間には注とんど関連はみ られない。

\section{VI. ヘマトクリット值と脳病変}

脳病変の性質とへマトクリット値との関連について は302例について検索を行ったが, 全体としてはへマト クリット值は約 $30 \%$ 前後で，老年者正常值に比しかな り低下しているが，一定の傾向は得られなかった。

\section{VII．非細菌性血栓性心内膜炎（NBTE） または心の壁在血栓と脳病変}

DIC 例にみられる脳虚血性病変が，DIC の直接の結 果といらょりも，同時にみられるNBTE, 左房または 左室の壁在血栓からの塞栓に基づく可能性，また，心 房細動, 心筋梗塞, 心筋症, 洞機能不全, 僧帽弁狭窄 症など，心疾患の併存と関連するか否かにつき検討を 行った。まず，上記のような心疾患の併存の及られな い198例につき, NBTE, 左房末たは左室の壁在血栓の ような塞栓源の有無と, 脳虚血性病変との関連につい て検討したところ，大梗塞执よび皮質梗塞の多発は塞 检源を有する43例中16例（37\%）にみられたが，塞栓 源のみられない 155 例中 4 例 $(3 \%)$ にみられたに過ぎ ず，両者間には有意差 $(\mathrm{p}<0.01)$ がみられた。病変 のみの例については, 前者 7 例 $(16 \%)$, 後者13例 ( $8 \%$ ) と有意差はみられなかったが，DIC に関連すると思わ れる虚血性病変の認められない例は，前者が20例 (47\%)，後者が138例 $(89 \%)$ と後者が有意 $(\mathrm{p}<0.01)$ に多かった。ただし，心疾患の併存のみられる55例に ついての同様の検索では，大梗塞および皮質梗塞の多 発は塞栓源を有する 18 例中 5 例 (28\%)，ならびに塞栓 源を有しない37例中 6 例（16\%）にみられ，塞栓源を 有しない例での病変発現頻度が高くなり（心疾患も塞 栓源も有しない例に比べて有意の差, $\mathrm{p}<0.01)$, 両者 間には有意の差がみられなくなっている，小病変のみ は前者に 2 例 $(11 \%)$, 後者で 7 例 $(19 \%)$, 脳病変の 


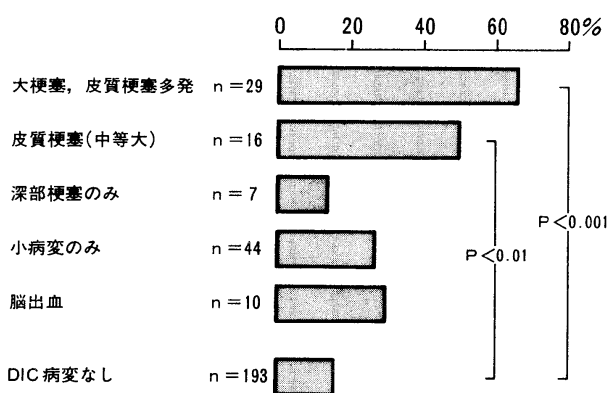

図 3 DIC 例に打ける脳病理所見と左心内塞栓源の 頻度
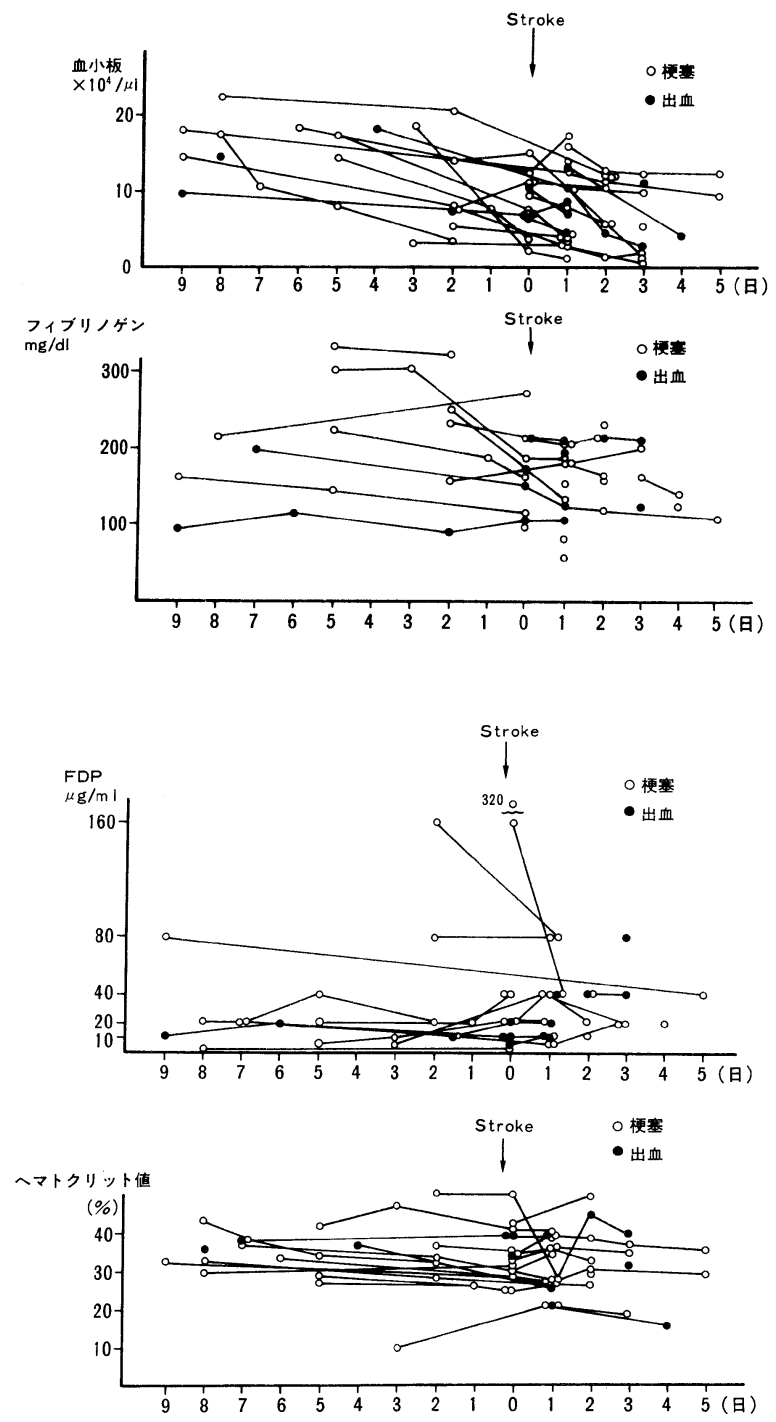

図 $4 \mathrm{DIC}$ 例における脳卒中発作発現前後の血小板, フィブリノゲン, FDP, ヘマトクリット值の変化
みられない例は前者で11例(61\%)，後者で24例(65\%) で,これも両者間に差がみられない（図 3 ).

\section{VIII. 脳梗塞または脳出血のみられた DIC 例に おける凝血能, ヘマトクリット值の変動}

血小板数(自動測定装置により測定)，フィブリノゲ ン量（自動測定装置を用いトロンビン時間法により測 定), FDP 量(ラテックス凝集法により測定), へマト クリット值の変動を図４亿まめて示したが，脳卒中発 作が DIC の初発症状であり, 発作後の凝血学的検索に より DICが発見された例が少数ながら認められた。

\section{IX. 考 察}

DICにおいては，さまざまな臓器症状がみられる が，このことは脳に関しても例外ではない, に著者らは, 老年者の DIC に際して脳動脈硬化が高度 であれば神経症状を発現しやすいこと音，また，DIC 例 中 NBTEを認める例に捛ける神経症状の発現頻度の 比較的高いこと ${ }^{9}$, 通常の脳梗塞の急性期にへマトク リット值が低值を示すことは少ない11のに，DICに合 併した例に招いては著しい貧血のみられることがある ことのなどを報告して来た．今回はさらに例数を増加 して検討を行って扮り,このほか, 大多数の例に積極 的にへパリン療法を行っているため，このことが臨床 症状, 病理組織学的所見を多少とも修飾している可能 性があるが，全体としては，従来の成績に比べ，とく にかけ離れた所見が得られたわけではない。

DIC と関連すると思われる脳病変としては, 虚血性 病変と出血性病変とが考光られるが, 一般的には虚血 性病変として時に大梗塞の発現がみられたのに対し， 出血性病変としては，小病変が主体であった。このこ とは, 一般に老人の DIC では消費性凝固障害之同時に 血小板の産生低下 (たと光ば急性白血病の存在), 凝固 因子の産生低下(たとえば劇症肝炎の存在), 著しい線 溶亢進（急性前骨䯣球性白血病や一部の悪性腫瘍例） が存在しない限り, 著明な出血傾向を呈することは比 較的少ないことによると思われる。

臨床的には，DIC 例にみられる片麻疩は，このよう な比較的大きい虚血性病変に関連することが多い反 面, DIC にしばしばみられる痉挛発作はむしろ小病変 のみを有する例にしばしばみられ，片麻痺と痉挛とが 同一例にみられることは稀であるので，両者の成因に は多少とも差のみられる可能性も考兄られる。たと兄 ば, NBTE や心の壁在血栓を有する例に大梗塞の発現 
頻度が高かったが，このことは，DIC に抒いてしばし

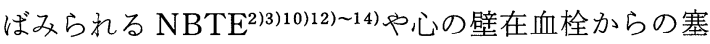
栓が DIC に抢ける脳病変の発現と密接に関与する可 能性を示している。ただし，NBTEや心の壁在血栓は DIC と全く無関係なのではなく，その成因はDIC に抏 ける凝固六進傾向之密接に関連すると思われる.

な抏，DIC の脳病変は全体としては䋃動脈の硬化度 とは無関係であり, 脳病変発現の基盤としては凝固穴 進状態の存在が考光られる。な抏，へマトクリット值 は血液粘度と正相関する15)ので，へマトクリット值が 低いことは循環障害を生じ難い方向に作用すると思わ れ，一般にへマトクリット值が低いDIC の例に脳病 变, 神経症状の夕られることも, 凝固六進の影響がへ マトクリット值の低下の影響をキャンセルする程強 かった結果と考光られる。

DIC の例でも, 病理組織学的に脳に虚血性なたは出 血性病変のみられない例では，代謝・循環障害を思わ せる血液所見のみられる例に神経症状の発現する頻度 が高く, DIC の例にみられ神経症状の全ては, 必ずし も DIC とは直接関連せず, 少なくともその一部は代謝 異常に基づく可能性も考えられる。ただし，このよう な代謝異常の発現に間接的にDICがかかわっている 可能性もあり，また，DICでは一般に血中の最も重要 な抗プラスミンである $\alpha_{2}$ プラスミン・インヒビターが 著しく低下しているため, 生じた血栓は溶解しやす く ${ }^{3)}$, 病理組織学的に血栓がみられなくても, 神経症状 の発現に DIC が関与している可能性も考兄られる.

以上，老年者に和ける DIC の発現頻度は比較的高い が，DIC は直接，間接にさまざまの神経症状の原因と なり得ると考兄られ，ことに比較的動脈硬化の軽度で ある例や，へマトクリット值の低い例に神経症状の発 現のみられた場合には，DICの有無につき検索を行 い, 適切な治療を行う必要があると思われる。

\section{文献}

1）松田保：DICの治療. 医学のあゆみ 109：
91-96, 1979.

2) Matsuda T, Yokouchi M, Murakami M: DIC in geriatric patients. Bibliotheca Haematologica $49: 225-237,1983$.

3）松田 保：DIC の臨床. 新興医学出版, 1983.

4) Minna JD, Robboy SJ, Colman RW: Disseminated Intravascular Coagulation in Man. CC Thomas, Springfield, 1974.

5）松田 保：血管内凝固症候群（DIC）。臨床血液 17 : 1139-1152, 1976.

6) Weber MB: The neurological complications of consumption coagulopathies. Neurology 18 : 185-188, 1968.

7) 荒木淑郎, 調 輝男: 血管内凝固症候群之神経系. 内科 $34: 251-256,1974$.

8）亀山正邦, 山之内博, 東儀英夫ほか：播種性血管内 凝固症候群 (DIC) 々脳血管障害. 神経内科 3 : 149-156, 1975.

9) 山之内博: DIC 症候群. 医学々薬学 2: 179-184, 1979.

10) Schwartzman RJ, Hill JB: Neurologic complications of disseminated intravascular coagulation. Neurology 32 : 791-797, 1982.

11）山之内博, 東儀英夫, 亀山正邦ほか：脳梗塞, 頭蓋 内出血発作前後に打ける末梢血液のへマトクリッ 卜值, へモグロビン值, 赤血球数, 血清総蛋白值の 変動。日老医誌 $13: 207-214,1976$.

12) Min K-W, Gyorkey F, Sato C: Mucin-producing adenocarcinomas and nonbacterial thrombotic endocarditis ; pathogenetic role of tumor mucin. Cancer $45: 2374-2382,1980$.

13) Pratt-Thomas HR, Smith RM, McMaster KR, et al: Intravascular mucinosis with mucin emboli and thrombosis accmpanying adenocarcinomas. Path Res Pract 170 : 328-337, 1980.

14) Matsuda $T$, Murakami $M$ : Relationship between fibrinogen and blood viscosity. Thromb Res 8 Suppl 2: 25-33, 1976. 
Abstract

\title{
Stroke and/or Cerebral Dysfunction in Geriatric Patients with DIC
}

\author{
Hiroshi Yamanouchi, Hiroshi Nakura and Tamotsu Matsuda*
}

Among 2,709 serial cases autopsied from July 1972 to March 1984 in Tokyo Metropolitan Geriatric Hospital, 375 cases $(13.8 \%)$ met the diagnostic criteria for disseminated intravascular coagulation (DIC), i.e. decrease in platelet count and plasma fibrinogen content, increase in concentration of fibrin degradation products (FDP) and presence of diseases caused DIC. From these 375 cases of DIC, 304 cases over age 60 without meningitis, respiratory brain and/or neurosurgical procedure were selected to investigate relationship between histopathological findings of brain and cerebral symptoms. These 304 cases included 158 patients with malignancy $(52 \%)$ and 37 ones with severe infection (12\%). Postmortem examinations of the brain revealed no abnormalities attributed to DIC in 192 cases $(63.1 \%) .68$ patients $(22.4 \%)$ had ischemic changes of brain including relatively large lesions, like large infarctions and/or multiple cortical infarctions. 21 patients $(6.9 \%)$ had hemorrhagic lesions mainly consisted of small multiple hemorrhage. The most common neurological mainfestations in patients with DIC were distur-

Tokyo Metropolitan Geratric Hospital and Kanazawa University, School of Medicine, 3rd Department of Internal Medicine* bances of conciousness, epileptic seizures and hemiplegia. In subjects in whom pathological changes in the brain were present, cerbral symptoms, especially hemiparesis were more frequently observed. In a few case, initial symptom of DIC was stroke. In patients without brain lesions compatible with DIC, incidence of neurological signs were higher in ones with metabolic abnormalities. Degree of sclerosis of cerebral arteries or hematocrit value did not correlate the incidence or character of neurologic complications in these cases, however, large infarctions or cortical infarctions were more frequently seen in patients with nonbacterial thrombotic endocarditis (NBTE) and/or mural thrombi in ventricle or atrium of the heart. From these results, it is concluded that neurologic complications are important in the aged patients with DIC. Some of these symptoms are attributed to metabolic disorders or thromboembolism from verrucca of NBTE and/or mural thrombi in the heart which are occasionally seen in cases of DIC. However, sclerotic changes in cerebral arteries or elevation of blood viscosity do not seem to influence the incidence of cerebral dysfunction in DIC.

key words: DIC, stroke, disturbance of conciousness, epileptic seizure, nonbacterial thrombotic endocarditis.

(Jpn J Geriat 22: 100-105, 1985) 


\title{
3. Amyloid angiopathy
}

\section{朝長 正徳}

\begin{abstract}
〈要 約 > Amyloid angiopathy (AA) による. 脳血管障害とくに脳出血の特徴を自験例および文献 例について検討し以下の結果を得た。

（1）70歳代を中心とした高齢者に多い，男女ほぼ同数にみられる.

(2) 高血圧の既往のあるものは少ない(22\%).

(3) 痴呆の有無は診断の決め手にならない $(36 \%)$.

（4）多発性出血（脳葉型）が多く (40\%) 再発することが多い. 出血部位は前頭葉が最も多い $(46 \%)$. 脳葉型出血の $20 \%$ が AA による。再発の誘因として, 外傷, 手術, 脳のバイオプシーなどがあげられる.

（5）血管病変は皮質小血管のアミロイドの沈着の活か，血管壊死，閉塞，線維化， duplicated wall な ぞが segmental にみられ，しばしば，多発性皮質梗塞をともなう。

老年者でリスクファクターのない脳葉型出血で多発し, 再発性の場合その原因として AA が考えられ る.
\end{abstract}

Key words：アミロイド・アンギオパチー, 脳出血, 脳葉型出血, 皮質梗塞, 血管壊死

\section{Amyloid angiopathy}

神経系のアミロイドーシスには主として末梢神経系 を和かす全身性アミロイドーシスと脳に限局する local amyloidosis がある. 前者はアミロイド・ニュー ロパチーであり, 後者は老人脳やアルッハイマー病で みられる老人斑と amyloid angiopathy (AA) である。 $\mathrm{AA}$ とは脳血管のアミロイド変性で脳の小動脈（angiopathie congophile, Pantelakis ${ }^{11}{ }^{1}$ 抌び毛細血管 (drusige Entartung, Scholz) ${ }^{2)}$ へのアロイドの沈着 である。すなわち，脳軟膜拉よび大脳皮質の小動脈の 中膜に限局してアミロイドの沈着したものが前者であ り，毛細血管壁に沈着し脳実質に向かってアミロイド がしみだした様に沈着したものが後者で, 同時にみら れることが多い。とくに後者は老人斑にともなってし ばしばみられる。

組織学的にはコンゴーレッド染色あるいはチオフラ ビン染色で染まり，特異な蛍光を発し，また偏光によ る重屈折をしめす。電子顕微鏡的には7 $9 \mathrm{~nm}$ 径のア ミロイド線維の沈着である。このアミロイド物質は他 の部分に沈着するアミロイドと同じ線維蛋白で X 線 解析で twisted-pleated sheet 構造をもっているが，そ の由来は不明である。しかし，過マンガン酸カリ前処

M. Tomonaga：東京都老人総合研究所臨床病理
置で抵抗性があり，免疫グロブリン抗体と結合するの で免疫グロブリン由来の AL 蛋白と考兄られている. 分子量は 6,000 であるがその一次構造は未知である。 た，アミロイドの沈着機序も不明であるが，種々な脳 に限局した炎症, 変性, 老化により障害されて脳の血 管の透過性の变化をきたし，これがアミロイド沈着の 基盤になる（angiopathie dyshorique, Morel）との説 もある。

AA は脳の老化と関連した変化で, 痴呆の有無にか かわらず高齢になるに従ってその頻度が高くなる。わ れわれの検索 ${ }^{34)}$ では60歳台 $8 \% ， 70$ 歳代23\%，80歳代 37\%，90歳代 $58 \%$ であった。男女差はない。この変化 の好発する部位は髄膜, 大脳皮質で, とくに側頭葉, 後頭葉で多く，血管壊死などの高血圧性小動脈変化の 好発する大脳基底核，脳幹などでは少ない。

\section{Amyloid angiopathy と脳血管障害}

AA を示するのの殆どは無症状であるが，この変化 はときに脳出血や皮質梗塞の原因となる。60歳以上の 老年者剖検70例の検索 ${ }^{5)}$ では, AA (+) のものは28例 あり，その内訳は男 6 , 女 22 例で, 60 歳代 0,70 歳代 4，80歳代11，90歳代14例と高齢者が多い。このうち, 脳血管障害のみられたものは23例 $(82 \%)$ で，そのう ち脳梗塞では小梗塞が多く（57\%）脳出血では大出血 が 4 例（17\%）に2られた. 小出血もふくめると出血 
は（31\%）に及ぶ。これは29例の AA の39\%に出血を みとめた Okazakiفi)の報告とほぼ同じ数字である。そ の他 SAH 1 例, SDH 2 例であった. 一方 AA (一) の42例の内訳は男19例，女23例で，60歳代 4, 70歳代 19，80歳代 $11 ， 90$ 歳代 8 例で90歳以下のものが多い. 脳血管障害は23例（50\%）にみいだされ，その内訳は， 脳梗塞は大小ともにみられ，脳出血では大出血は 7 例 （10\%）でAA 群よりすくなく，小出血の方が多かっ たＳSDHは 3 例にみられた。高血圧を有するすのは $\mathrm{AA}(+)$ で20例 (71\%) で AA (-) の26例 (62\%) よりやや多かった，脳底部の動脈硬化は高度なるのは $\mathrm{AA}(+)$ で12例 (43\%)に比べ, AA (-)で8例(19\%) とすくなかった。しかし，AA と関係の深い老人斑は $\mathrm{AA}(+)$ で19例 (68\%) と AA (-) の6 例 (14\%)

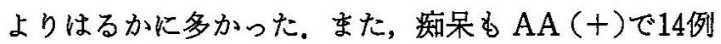
(58\%), AA (-) で12例 (41\%) で AA (+) の例に 多かった。

この様に $\mathrm{AA}(+) の$ 群に脳血管障害が多いが，その 中には高血圧性のもの，動脈硬化によるものがふくま れていると考えられる。文献例では AA による脳出血 は脳出血の $3.7 \%$ あいは $9.3 \%$ 占めるとされる.

\section{3. 脳葉型出血と $\mathbf{A A}$}

高齢者での脳葉型出血の場合 AA によるものを考 慮すべきといわれる(図 1)，われわれの経験した39例 の lobar hematoma (LH) のうち，もっとも多いのは 高血压性のもので, 次いで AA, 脳腫場, 出血傾向によ るものであり，LH の原因としての AA の頻度は決し て少なくない(表 1)。乙たがって，高血压などのリス クのない高龄者の LH の場合，鑑別上 AA を考学る必 要がある。

AA によると考えられる LH を示した 8 例は，70歳 代 3 例，80歳代 4 例，90歳代 1 例で70歳以下はなかっ た．男 3 ，女 5 で，高血圧は 3 例（37.5\%）にみとめ られた。 5 例に痴呆がみられた $(62.5 \%)$ ．血踵の部位 は前頭葉 5 , 頭頂葉 1 , 側頭葉 4 , 後頭葉 2 で前頭葉, 側頭葉に多く，4例で血腫は複数であった（50\%）全 例にくも膜下出血がみられ，皮質梗塞は 5 例で著名で あった（表 2 ).

ちなみに LH は脳出血230例中17\%にみられ，従っ てAAによると考克られるすのは全脳出血の $3.5 \%$ に 相当する。

現在まで娭索できた AA による LH 例の報告は 17 あり，少なくとも68例が記載されている。それをる

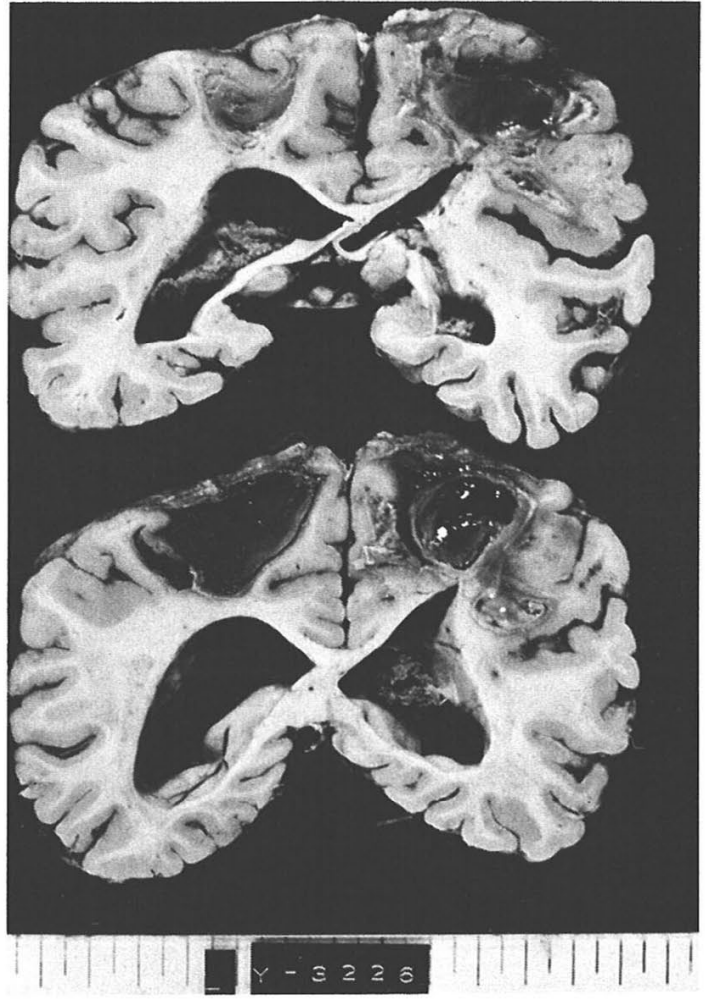

図 1 多発性脳出血(脳葉型)，80歳男

表 1 Causes of lobar cerebral hemorrhage(39 cases)

\begin{tabular}{l|c|c}
\hline & No. of cases & \% of total \\
\hline Hypertension & 14 & 35.8 \\
Amyloid angiopathy & 8 & 20.5 \\
Neoplasm & 6 & 15.4 \\
Hemorrhagic diathesis & 4 & 10.3 \\
Aneurysm & 3 & 7.7 \\
Vascular malformation & 1 & 2.6 \\
Unknown etiology & 3 & 7.7 \\
\hline \multicolumn{1}{c|}{ Total } & 39 & 100 \\
\hline
\end{tabular}

めてみると, 年齢は45歳から94歳まであり, 平均73.26 歳である，男女ほ注同数で，高血王のあったるのは少 なく，ないものが77\%を占めている。痴呆は $36.4 \%$ に みられるにすぎない，出血は多発性のものが $39.7 \%$ 瓜

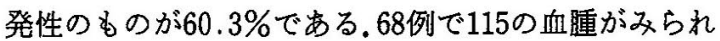
ているが，その部位は前頭葉が $46.1 \%$ と最も多く。つ いで頭頂葉, 側頭葉, 後頭葉の順であった. くも膜下

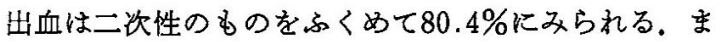
た, 老人斑やアルッハイマー原織維変化など老年変化 
表 2

\begin{tabular}{|c|c|c|c|c|c|c|c|}
\hline \multirow[b]{2}{*}{ Age } & \multirow[b]{2}{*}{ Sex } & \multirow[b]{2}{*}{ HT } & \multirow[b]{2}{*}{ Dementia } & \multirow[b]{2}{*}{ Clinical features } & \multicolumn{3}{|c|}{ Pathological findings } \\
\hline & & & & & $\begin{array}{l}\text { location of } \\
\text { hemorrhage }\end{array}$ & sec. SAH & $\begin{array}{l}\text { cortical } \\
\text { infarct. }\end{array}$ \\
\hline $92 y$ & $\mathrm{f}$ & + & - & tetraplegia, coma & 1t-Temporal & + & - \\
\hline $78 \mathrm{y}$ & $\mathrm{m}$ & - & + & dementia, frontal sign & rt-Frontal & + & 世 \\
\hline $85 y$ & $\mathrm{f}$ & - & + & dementia, rt-pyramidal sign & $\left(\begin{array}{l}\text { rt-Temporal } \\
\text { lt-Occipital }\end{array}\right.$ & + & + \\
\hline $80 \mathrm{y}$ & $\mathrm{m}$ & - & + & $\begin{array}{l}\text { lt-hemiparesis } \\
\rightarrow \text { rt-hemiparesis }\end{array}$ & $\left(\begin{array}{l}\text { lt-Frontal } \\
\text { bi-Parietal }\end{array}\right.$ & + & H \\
\hline $73 y$ & $\mathrm{f}$ & + & $\stackrel{+}{\text { (Apallic) }}$ & $\underset{\rightarrow \text { rt-hemiparesis }}{\rightarrow \text { tetraplegia }}$ & $\left(\begin{array}{l}\text { lt-Frontal } \\
\text { bi-Parietal } \\
\text { bi-Occipital }\end{array}\right.$ & + & H \\
\hline $86 y$ & $\mathrm{f}$ & - & - & lt-hemiplegia, coma & rt-Temporal & + & - \\
\hline $80 y$ & $\mathrm{f}$ & + & $\stackrel{+}{+}$ & lt-hemiparesis & $\left(\begin{array}{l}\text { rt-Frontal } \\
\text { lt-Temporal } \\
\quad \text { (evacuation) }\end{array}\right.$ & + & + \\
\hline $71 \mathrm{y}$ & $\mathrm{m}$ & - & - & meningeal irritation, coma & rt-Frontal & + & - \\
\hline
\end{tabular}

表 3 Amyloid angiopathy による脳葉型 出血例68例(17報告)のまとめ

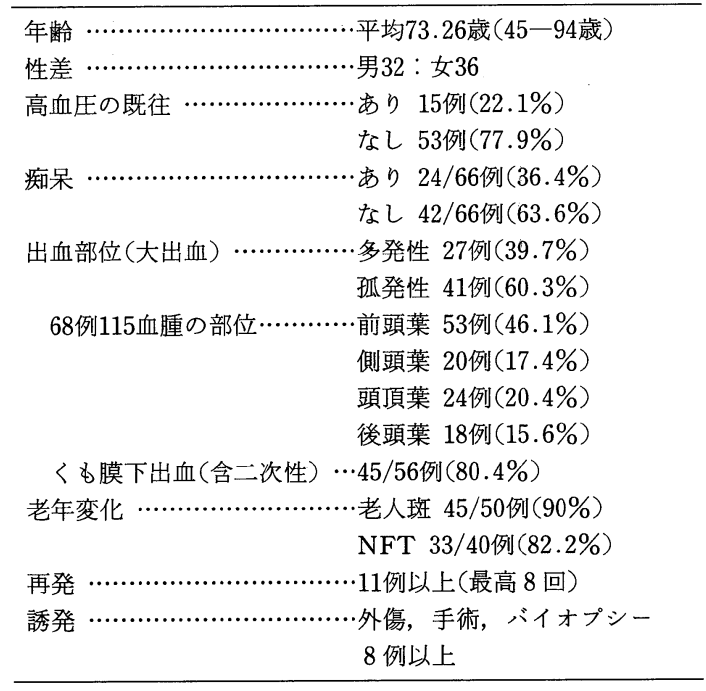

の出現頻度は高い. LH の再発は11例以上にみられ, 最 高 8 回であった，CTでの追跡で血腫が15個みられた 例もある. その誘発因子として, 外傷, 手術, バイオ プシーなどの侵襲があげられる（表 3 ）.

\section{AA による脳血管障害例の病理所見}

出血のみられる例では，アミロイド変性におちいっ た血管の壁がこわれ(duplication)，また血管壁のヒア リン化や壊死を示し，しばしば小動脈瘤を形成する。 これが血管破綻のもとになっていると考えられる。こ の様な血管変化の多発する例では血管の内腔狭窄や器
質化による閉塞がみられ，しばしば多数の大脳皮質小 梗塞巣を示す.連続切片により病変を追跡してみると, この様な変化はアミロイド沈着部位に近くみられ segmental な分布をとっている。これは高血王のない 例にもみられるが，高血圧が加わるとさらに変化を促 進し，出血の原因になると思われる。この様な血管変 化の機序は不明であるが，免疫異常も含めなんらかの 血管炎を想定しているものもいる。すなわち，側頭動 脈炎, リュウマチ性疾患などとの関係が考えられる. この様な血管の閉塞は皮質梗塞の原因になる。

今後, 人口の高齢化とともにこの様なかたちの脳血 管障害が増えてくるものと考学られる。

共同研究者：吉村正博, 森 秀生(東京都老人総合研究所 臨床病理), 嶋田裕之, 江崎芳行, 山之内博, 葛原茂樹 (東 京都養育院付属病院), 羽生春夫, 桜井博文 (東京医大老年 科), 美馬達夫 (富士脳研), 富本浩明 (京大神経内科), 長 沢治夫 (東北大神経内科), 須田恵美子 (東京女子医大神経 内科)，東儀英夫（岩手医大神経内科）

\section{文献}

1) Pantelakis $S:$ Un type particulier d' angiopathie senile du systeme nerveau central : Un angiopathie congophile. Monatschr Psychiat Neurol 198 : 219-256, 1954.

2) Scholz W: Studien zur Pathologie der Hirngefässe. II. Die drusige Entartung der Hirnarterien und capillaren. Ztschr Neurol Psychiat $162: 694-715,1938$.

3) Tomonaga $\mathrm{M}$ : Cerebral amyloid angiopathy in the elderly. J Am Geriat Soc 29: 151-157, 
1981.

4) 朝長正徳：脳のアミロイド・アンギオパチー. 神経 内科 $12: 244-253,1980$.

5）朝長正徳 : 老人疾患とアミロイド, 基礎と臨床. 脳 の老化とアミロイド。日老医誌 $19: 359-363$, 1982.

6) Okazaki H, Reagen $T$, Campbell RJ : Clinicopathologic studies of primary cerebral amyloid angiopathy. Mayo Clin Proc 54 : $22-31,1979$.

7）朝長正徳：アミロイドと脳血管. Geriatric Med $20: 777-782,1982$.

8) Mandybur TL: Cerebral amyloid angiopathy: Possible relationship to rheumatoid vasculitis. Neurol $29: 1336-1340,1979$.

Abstract

\title{
Amyloid Angiopathy
}

\author{
Masanori Tomonaga, M.D.
}

The cerebrovascular disturbance, particularly cerebral bleeding, due to cerebral amyloid angiopathy of the elderly persons was examined on the autopsy cases of Tokyo Metropolitan Geriatric Hospital and reported cases in the literature. The characteristic features were as follows:

1. It was observed in the elderly persons age over 70 and there was no sex difference.

2. History of hypertension was observed in a few cases (22\%).

3. Dementia was not always a combined symptom $(36 \%)$.

Department of Clinical Pathology, Tokyo Metropolitan Institute of Gerontology
4. Multiple lobar hemorrhage was frequent $(40 \%)$ and often recurrent. This consisted of $20 \%$ of lobar type cerebral hemorrhages. Hematomas in the frontal lobe were most frequent $(46 \%)$.

5. In addition to amyloid diposition, several vascular changes, such as hyalinosis, angionecrosis, duplication, fibrosis and occlusion of cortical arterioles, were observed in segmental fashion, often accompanied by multiple cortical infarctions.

The lobar type hemorrhage, sometimes recurrent, observed in the elderly persons without any risk factor was strongly suspected of amyloid angiopathy as a cause.

key words: amyloid angiopathy, cerebral bleeding, lobar type hemorrhage, angionecrosis, cortical infarction (Jpn J Geriat 22: 106-109, 1985) 
くシンポジウム：特異な原因による老年者の脳卒中 $>$

\title{
4. 老年者にみられる血管炎
}

緒方絢

\begin{abstract}
＜要 約＞ 中枢神経系を侵かす血管炎のうち，老年者により頻回みられるものとして側頭動脈炎と帯 状席疹に伴ら脳卒中が挙げられる，四つの施設にてすでに報告された両疾患 7 例を検討し，文献的考察 を加光た。

側頭動脈炎は，高齢者の側頭動脈に起こる巨細胞を伴う肉芽腫性動脈炎である，頭蓋，頝部，眼動脈 も侵され，失明，脳梗塞が起こることがある．本疾患の原因として加齢による動脈壁の弾性板の変性に 伴う免疫学的機序が考光られているが，成因は不明である，ステロイドホルモンの長期投与が治療の基 本で, 通常生命への予後は良好である.

帯状疮疹は通常の免疫能力を有するものについては，加齢と共にその発症頻度は増加する，帯状疮疹 に続発して脳卒中が起こることがあり，帯状疮疹ウイルスが末梢神経系経由で脳底部動脈に伝播し，そ の部に動脈炎を起こすためと考号れている，多くの場合動脈の炎症に伴う血栓性閉塞による脳梗塞で あるが, 病変部が破綻し，〈も膜下出血を来たす場合もある。带状疮疹に伴ら脳卒中の報告は43例みら れ, その年齢分布は带状疮疹全例のそれに注济一致する. 治療としては抗水痘, 帯状疱疹薬投与が必要 である。

今後老年者人口が増加することは明らかで，このよらな疾患の存在を認識することの必要性を強調し た.
\end{abstract}

Key words : 老年者, 中枢神経系, 血管炎, 側頭動脈炎, 帯状疱疹に伴う脳卒中

\section{緒 言}

中枢神経系を直接あるいは間接的に侵かす血管炎の らち，老年者により頻回みられるものとして，側頭動 脈炎 (以下 TA) と帯状疱疹 (以下 $\mathrm{HZ}$ ) に伴う脳卒中 が挙げられる。近年両疾患の報告は増加しており, 今 後更に老年者人口が増加することは明らかで，これら の疾患を認識することは重要である。

\section{方法}

四つの施設にて，すでに報告された TA 6 例 ${ }^{1) \sim 3), ~}$ $\mathrm{HZ}$ に伴う脳卒中の 1 例 ${ }^{4}$ について, 臨床像拉よび病理 組織所見を検索し，文献的考察を加光た。

\section{成績および考察}

I. 側頭動脈炎 ${ }^{5) 6)}$

1934年の Horton らの報告以来, 同様の症例が数多 く報告され, Hortonらが示した症例よりも幅広い病 態を示すことが明らかになった。

J. Ogata：国立循環器病センター研究所
年龄, 性差：主として60歳以上の老年者に発症し, 男女差は欧米で女にやや多く, 本邦ではほぼ同数であ る。欧米の白人に括ける報告は多いが，本邦での報告 は少ない。本邦に扔いて臨床像と浅側頭動脈の生検所 見より TAの診断を確定した最初の報告は亀山ら （1966）によるものである。本邦における報告は近年増 加し，1983年末までに88例がみられる（図 1).

症状：微熱, 倦怠感, 食思不振などの全身症状が数 週から数カ月続く. TA 例の $20 ８ 0 \%$ はリウマチ性多 発筋痛症 (polymyalgia rheumatica, 以下 PMR) を呈 する. 側頭, 頭頂部に疼痛が比較的急速に出現する. 浅側頭, または後頭動脈が腫脹して固く, 圧痛を伴い, 拍動が減弱をたは消失する。

本疾患の最も重要な合併症として, 視力障害あるい は失明が挙げられる。頭蓋, 頝部動脈の閉塞による脳 虚血性病変による局所神経症状, 精神症状がみられる. 欧米に掞いては解離性大動脈瘤, 心筋梗塞などが報告 されている。

検查所見: 浅側頭動脈生検にて, 巨細胞を伴う肉芽 腫性動脈炎を証明することが診断の基本となる. 確実 に病変部を生検する目的で行う脳血管撮影, 特に外䅡 


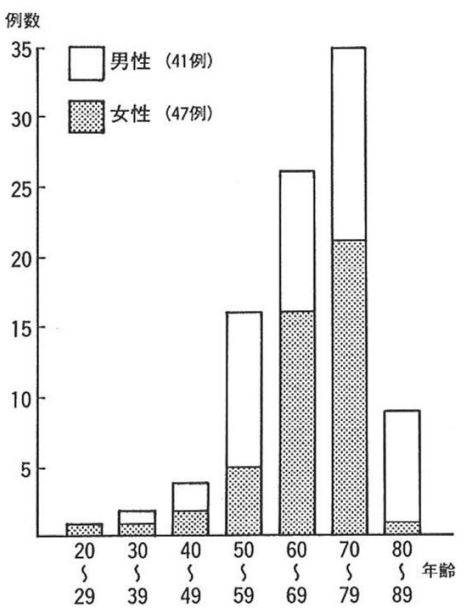

図 1 側頭動脈炎の年龄分布（本邦報告例, 1960 1983)

動脈の選択的造影の臨床的価値は高い。

他に特徵的な検查所見はない.赤沈穴進がみられる。 免疫グロブリン， $\alpha_{2}-$ グロブリン，補体価が増加してい る場合がある。

治療, 予後：ステロイドホルモンへの反応は良好で あるが，長期投与が必要である。重篤な合併症がなけ れば生命予後への関与は極めて少ない。

病理学的所見：浅側頭動脈あるいは他の中等大もし くは大きな頭蓋抢よび䅡部動脈に病変が出現する。動 脈障害の部位別頻度を Wilkinson, Russell (1972) が 12例を基にして顕わした成績がある。浅側頭，椎骨， 眼, 後毛样体動脈に $75 \sim 100 \%$, 浅側頭動脈以外の外䅡 動脈枝, 内頝動脈の petrous と cavernous segments, 網膜中心動脈近位部に $38 \sim 60 \%$, 網膜中心動脈遠位部 に26\%の頻度で重篤な病変がみられ, 頝部内頝動脈, 総頝動脈, 頭蓋内動脈には軽度の病変が10２5\%にみ られた。をた脳病変としては， 7 例に視神経， 2 例に 両側後頭葉, 6 例に脳幹と小脳, 4 例に大脳半球の梗 塞がみられた。

生検された浅側頭動脈には病理組織学的に资症反応 が全層性にみられ, 動脈壁は膨化し,内腔は血栓を伴っ て狭窄あるいは閉塞している。リンハ球, 形質球, 組 織球，線維芽球，マクロフフージ，多核巨細胞からな る肉芽腫性炎症がみっられ，内膜と中膜の境界部に著し い.内弾性板の变性, 断裂, 消失が不規則にみられ, 多核巨細胞がその部位に集中的に出現する傾向があ る.

図 $2 ， 3$ に75歳女性に打ける $\mathrm{TA}^{2)}$ の生検組織を示

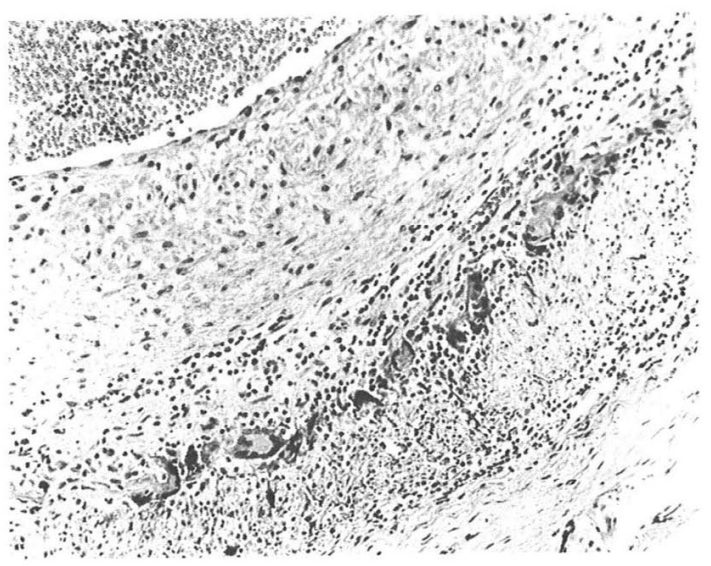

図 2 浅側頭動脈生検所見. 多核巨細胞を伴う肉芽腫 性動脈炎. H.E. $\times 97$.

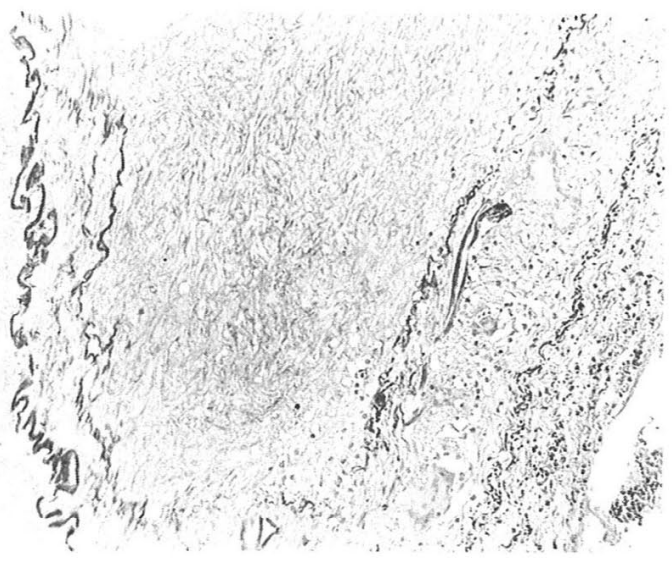

図 3 浅側頭動脈生検所見. 内弾性板が断裂，消失し た部位に多核巨細胞がみられる. Elastica van Gieson $\times 97$.

す. 生検が行われたのは 6 カ月間ステロイドホルモン が投与された後である。多核巨細胞を伴う肉芽腫性炎 症細胞浸潤が内膜外層より中膜にかけてみられ，内膜 に増殖性変化がみられる.内弾性板が断裂，消失した 部位に多核巨細胞が出現している.

欧米における剖検例の検索によると, 浅倒頭動脈に みられるるのと同様の炎症所見が全身の中等大あるい は大きな動脈に単発性あるいは様々の組み合わせで存 在する，小動脈は通常侵されない，冠動脈病変により 狭心症あるいは心筋梗塞が起こる場合があり，また大 動脈病变により大動脈瘤, 大動脈弁閉鎖不全, 大動脈 の解離, 破裂が起こる。亀山ら（1974）は臨床像と生 
検にてTA と診断され，ステロイドホルモン投与によ り軽快していたが，5年後に急死した 73 歳の女性を剖 検し，大動脈起始部の解離性大動脈瘤の破裂による心 タンポナーデを認めた。組織学的には大動脈の中膜の 弾性板の消失が高度で, 破裂部位近くに円形細胞の浸 潤と多核巨細胞の出現をみた。また総頝動脈の中膜お よび外膜に円形細胞の浸潤をみた。

同様の動脈病変は大動脈から直接分岐する主幹動脈 にもみられ，大動脈弓症候群，四肢の claudicationを 呈することもある。腎動脈病変が起こっても腎血管性 高血圧を来たす程の狭窄を起こすことはない。

浅側頭動脈に局所症状がなく，生検にて異常を見出 せぬ場合でも他の動脈に巨細胞を伴う肉芽腫性炎症が みられる場合がある。このような症例に打いては TA といら名称は単に部位を強調し, 他の動脈病変を無視 するものであるため，巨細胞動脈炎（GCA）といら名 称が使われる。

成因：病理組織学的に弾性板の崩壊とその近傍の肉 芽腫性炎症が病変の主体をなすので，加齢に伴う崩壊 した動脈壁のエラスチンが異物となって起こる異物反 応，自己免疫，感染症などが考兄られ，免疫学的手法 による研究が進められている.

動物実験でェラスチンが抗原となり得ること，エラ スチンを組織に注入すると GCA に類似した組織反応 が起こることが証明されている．TA 例の血清に免疫 グロブリン, 補体価の上昇がみられ, 生検組織にこれ らが沈着しているのが認められる場合がある，病変部 の動脈壁にはTリンパ球が浸潤して㧊り，Bリンパ球 はみられなかったとの報告があり，動脈壁抗原に感作 された Tリンパ球の炎症への関与が示唆されている.

また PMR 例に打いて数多くのウイルス抗体を検索 し，HBsAb 陽性例が対照群に比して多かったとの報 告がある，免疫応答機構に変様を来たしている高年者 に何らかの感染が起こった場合，異常な免疫応答が現 われる可能性が考えられる. 生検組織の電䫓的検索に ては, ウイルスと思われる構造物は発見されていない。

以上の如く, TA の成因には免疫機序の関与が強く 示唆されるが，成因は不明である。

II. 帯状疱疹に伴う脳血管障害

$\mathrm{HZ}$ に伴う神経系の障害には，1．神経炎（感覚抢よ び運動性)，2．脊髄炎，3，脳炎，4，脳血管障害（脳 炎を伴わない）が知られている。

帯状疮疹に伴了脳梗塞：眼部帯状疮疹 (HZO) 飞続 発する対側片麻痺の頻度は低いが，近年報告が増加し

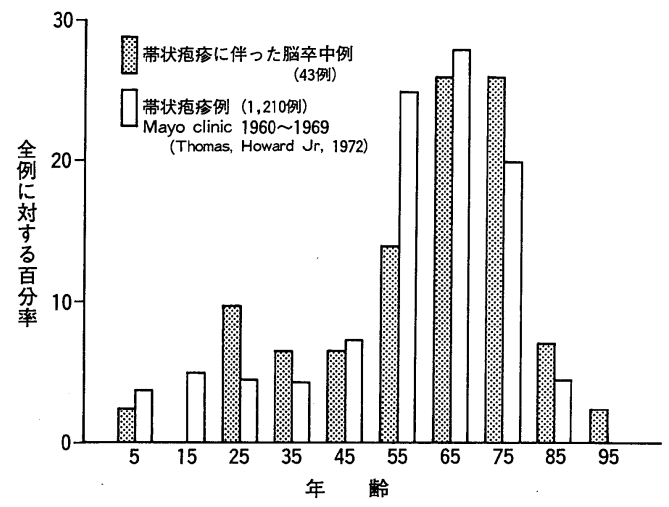

図 4.帯状疱疹とそれに伴った脳卒中例の年齢分布

て扮り，本邦での報告は 7 例みられる. $\mathrm{HZO}$ 出現後, 平均 8 週間後にみられる.片麻瘏の発現様式は TIA が 先行するもの, 突発性あるいは段階的増悪などである. 本疾患を診断するには，まず臨床的に本疾患であるこ とを疑い，脳血管撮影にて診断される。脳血管撮影に て, 中, 前大脳動脈の近位部, 内頝動脈のサイフォン 部に segmental な狭窄がみられる。両側性に動脈病変 がみられる場合もある78). 頭部 CT にて動脈病変に相 当した低吸収領域がみられる.HZO の場合通常内額動 脈領域に梗塞が出現するが，同側の小脳梗塞を来たし た症例もある ${ }^{9)}$.

病理組織学的には，狭窄を来たした動脈に巨細胞を 伴う肉芽腫性炎症がみられる。

また病変部に内弾性板の崩壊, 消失がみられ

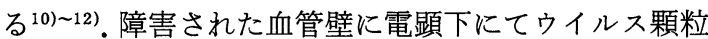
が認められている(10)11). $\mathrm{HZO}$ と動脈病変部位が近接し ていることから，三叉神経節，三叉神経経由で頭蓋内 動脈にウイルスが直接伝播すると考えられている。 たかなりの頻度で，外，内眼筋麻痷が起こる。これは 三叉神経節から海綿静脈洞にウイルスが伝播し，これ らの脳神経を侵すと考光られている。また海綿静脈洞 内での三叉神経第 1 枝から内頝動脈へのウイルスの伝 播も考兄られている8113).

片麻痺のみでなく, 失語, 構語障害, 半盲, 半身感 覚障害, 半側空間失認, 小脳性失調, 精神症状などが 報告されている，HZ 亿伴う脳卒中の再発は報告され ていない，本疾患に抢ける死亡率は低( 8)13).

帯状疮疹に伴ったくも膜下出血：田中ら ${ }^{4)}$ は, 左側 の後頭部より項部 $\left(\mathrm{C}_{2}\right.$ 支配領域) の帯状疮疹後, 2 力 月してくも膜下出血を来たし，20時間で死亡した71歳 の男性の剖検例を報告した。血清の $\mathrm{HZ}$ ウイルス抗体 
価は $\mathrm{HZ}$ 発症後 1 カ月, 1 カ月半で 32 倍, 2 カ月で 16 倍であった(正常域：4 倍以下). 全身臓器所見として は心肥大（心重量 $430 \mathrm{~g}$ ) があるのみで, 脳底動脈に紡 錘状に拡張した動脈瘤があり，その破綻によるくも膜 下出血がみられた。破綻部の血管壁に多核巨細胞を伴 ら肉芽腫性炎症がみられた. 内膜にはリンパ球を主体 とした炎性細胞浸潤, 中膜付近には組織球の浸潤があ り, 外膜にも炎性細胞浸潤がみられた。炎症による内 弾性板の断裂が著明に認められた。脳底動脈以外の脳 底部動脈および脳実質には炎症性変化はみられなかっ た。

脳底動脈病変部の中膜に浸潤した組織球様細胞の細 胞質に直径150 220nm のエンベロップを有するウイ ルス顆粒が電顕下にて認められた。これはへルペス族 ウイルスとして矛盾しないと考兄られた。 また免疫組 織学的に $\mathrm{HZ}$ ウイルス抗原の存在を組織球様細胞の細 胞質抒よび核内に認めたが，単純へルペス抗原は認め られなかった。本症例は, 脳底動脈に $\mathrm{HZ}$ ウイルスに よる肉芽腫性血管炎が生じ, それが破綻してくも膜下 出血を来たした症例として最初の報告である.

Ojèda ら ${ }^{12)}$ は一側頭皮と頝部の $\mathrm{HZ}$ で橋の梗塞を来 たした例で，橋周囲の小動脈に動脈炎をみている。本 症例は田中ら ${ }^{4)}$ が報告した症例の血管障害部位と一致 する.

Gürsoy $5^{14)}$ は左側 $\mathrm{HZO}$ 出現後 1 週間して対側片 麻痄を来した 24 歳の女性を報告した. $\mathrm{HZO}$ 出現 5 週間 後に行った脳血管撮影にて, 左内頝動脈の petrous portion $2 \times 2 \times 2.5 \mathrm{~cm}$.の大ささの動脈瘤を見出した. 以 上の如く, HZ に伴って脳動脈瘤, くも膜下出血が出現 する場合がある。

検查所見：脳血管撮影, 頭部 CT は重要な検查であ る. 脳脊髄液にリンパ液, 多核白血球からなる細胞数 増多, 蛋白量増加, キサントクロミーがみられる場合 がある。

$\mathrm{HZ}$ ウイルスの抗体価の上昇が血清, 脳脊䯣液にみ られる8).

帯状疮疹と加齢あるいは基礎疾患との関連：HZの 発症頻度は, 通常の免疫能を有するものに拈いては加 齢と共に増加する。これは老年者に和ける免疫能の低 下, 特に細胞性免疫能低下が関与すると考兄られる。 また悪性腫瘍, 特にリンパ組織の悪性腫瘍または白血 病, さらには抗癌薬投与, 放射線療法に伴った免疫能 低下例に HZ が出現することが多い12). HZ に伴った 脳梗塞あるいはくも膜下出血を呈した報告例 43 例の年
齢分布をみると，Thomas, Howard ${ }^{15)}$ が報告した $\mathrm{HZ}$ 全例の年齢分布とほぼ一致し，60歳代，70歳代にその peakをみる。

治療：皮虐, 眼病変に対する治療は勿論必要である. 脳血管病変に対して，ステロイドホルモンが投与され る場合があるが，その効果は確定していない、TIAを 呈した症例に抗凝固療法を行ったとの報告があるが, この効果も確定していない( ${ }^{8)}$. 本質的な治療は, 抗水 痘，HZウイルス薬を投与することで, vidarabine, acyclovir の効果は確定している16).

中枢神経系の巨細胞性血管炎との関連：Giant cell granulomatous angiitis of the central neruous sys-

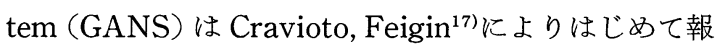
告された疾患で, 成人に発症し, 進行性の局在性ある いは広範な神経症状が出現し, 生命予後は悪い。組織 学的に種々の古さの, リンパ球, 形質球, 組織球, 線 維芽球，多核巨細胞からなる肉芽腫性炎症が，軟膜あ るいは脳実質内の小動脈，小静脈㧍よびその周囲にみ られる。脳底部主要動脈が侵されることもある。これ らの血管病変により脳梗塞を来たす ${ }^{-18)}$.

HZ に伴う動脈炎と GANS は病理組織学的に overlap している所があり，HZに伴った動脈炎は GANS の subgroup の 1つであるともい党る。また GANS と して報告された症例のらち，HZが起こったことを患 者が忘れていたり, subclinical な感染があった可能性 もある。

研究協力者: 田代幹雄, 山口武典 (国立循環器病セン タ一, 内科脳血管部門) 由谷親夫 (同病理), 中尾雄三 (近 畿大学医学部眼科), 矢野 隆 (国家公務員共済組合連合会 浜の町病院内科), 福本純雄, 田中健蔵 (九州大学医学部第 1 病理), 竹下司恭 (九州労㷋病院)

\section{文献}

1）向井常博, 鬼木秀夫, 竹下司恭, 渡辺英伸, 大国音 三郎：側頭動脈炎（temporal arteritis）の一例. 臨林之研究 $48: 1227-1231,1971$.

2) 田代幹雄, 山口武典, 由谷親夫, 中尾雄三, 唐沢 淳, 飯塚修三：側頭動脈炎の 1 例. 日内会誌 69 : 1172-1173, 1980.

3）矢野 隆，他：側頭動脈炎の 4 例。共済医報 1985 (投稿中)

4）田中健蔵, 福本純雄, 金城 満, 永田忍彦, 外村慶 蔵：帯状疮疹ウイルスによると考兄られる脳底動 脈の肉芽腫性血管炎の一剖検例. 厚生省特定疾患, 系統的血管病変に関する調査研究班，1983年度研 
究報告書, $\mathrm{p} 269-272$.

5）田中健蔵, 緒方 絢：側頭動脈炎. 現代病理学大系 (吉 利和, 他編), 中山畫店, 東京, 1985(印刷中).

6) 田中健蔵, 緒方 絢: 巨細胞動脈炎. 現代病理学大 系 (吉 利和, 他編), 中山書店, 東京, 1985 (印 刷中).

7) MacKenzie RA, Forbes GS, Karnes WE: Angiographic findings in herpes zoster arteritis. Ann Neurol 10:458-464, 1981.

8) Bourdette DN, Rosenberg NL, Yatsu FM: Herpes zoster ophthalmicus and delayed ipsilateral cerebral infarction. Neurology 33 : 1428-1432, 1983.

9）山本辰紀, 辻 貞俊, 大石智世, 井上尚英, 村井由 之：同側の小脳半球梗塞を続発した右眼部帯状疱 疹の一例. 第85回日本神経学会九州地方会, 1984 .

10) Linnemann CC Jr, Alvira MM : Pathogenesis of varicella-zoster angiitis in the CNS. Arch Neurol 37 : 239-240, 1980.

11) Doyle PW, Gibson G, Dolman CL: Herpes zoster ophthalmicus with contralateral hemiplegia : Identification of cause. Ann Neurol 14 : 84-85, 1983.

12) Ojeda VJ, Peters DM, Spagnolo DV: Giant cell granulomatous angiitis of the central ner- vous system in a patient with leukemia and cutaneous herpes zoster. Am J Clin Pathol 81 : 529-532, 1984.

13) Chan C, Huffaker G: Herpes zoster ophthalmicus with contralateral hemiparesis. A case report and review of the literature. $\mathrm{J}$ Clin Neuro-ophthalmol 3: 111-114, 1983.

14) Gürsoy G, Aktin E, Bahar S, Tolun R, Özden B : Post-herpetic aneurysm in the intrapetrosal portion of the internal carotid artery. Neuroradiol $19: 279-282,1980$.

15) Thomas JE, Howard FM Jr: Segmental zoster paresis-A disease profile. Neurology 22 : 459-466, 1972.

16) Hirsch MS, Schooley RT: Treatment of herpesvirus infections. New Eng J Med 309 : 963-970, 1034-1039, 1983.

17) Cravioto $H$, Feigin $I$ : Noninfectious granulonatous angiitis with a predilection for the central nervous system. Neurology 9 : 599-608, 1959.

18) Nurick S, Blackwood W, Mair WGP: Giant cell granulomatous angiitis of the central nervous system. Brain 95 : 133-142, 1972. 
Abstract

\title{
Vasculitis as a Cause of Cerebrovascular Disease Among the Elderly
}

\author{
Jun Ogata, M.D.
}

Among the various vasculitis which involves central nervous system, temporal arteritis and delayed cerebrovascular diseases occurring after ophthalmic or cutaneous herpes zoster are known to affect particularly elderly individuals. Clicical and pathological features of seven cases of both diseases, which were already reported from four institutes, were investigated, and a review of the literature was made. The purpose of this presentation is to alert clinicians to these diseases so that one will be prepared when confronted by such patients. -

Temporal arteritis is a giant-cell granulomatous arteritis involving the temporal artery and other arteries in the cranium and neck among the elderly. Involvement of these arteries results in visual impairment and cerebral infarction. Immunological derangement associated with degeneration of the elastic lamina of the arterial wall in the elderly individuals is considered to be the cause of the diseases, however, the etiology is as yet unknown. Treatment consists of long-term administration of corticosteroids. Mortality of this disease is low.

Research Institute, National Cardiovascular Center
Arteritis of the intracranial vessels can evolve as a consequence ophthalmic cutaneous herpes zoster and results in cerebrovascular diseases. The risk of the arteritis and stroke following herpes zoster infection seems low. In ophthalmic herpes zoster, direct spread of the virions from the trigeminal ganglion to adjacent intracranial arteries has been postulated to be the route of infection. In most cases, cerebral infarction ensues from thrombotic occlusion of the affected arteries, however, the affected arteries rarely ruptures resulting in subarachnoid hemorrhage. There have been 43 reported cases of herpes zoster infection and delayed cerebrovascular diseases in the world literature. Ophthalmic or cutaneous herpes zoster is a frequent occurrence among the elderly. The age distribution of herpes zoster infection with delayed cerebrovascular diseases resembles that of overall herpes zoster infection. Anti-herpes agents such as vidarabine or acyclovir are proved to be effective to herpes zoster infection.

key words: elderly individual, central nervous system, vasculitis, temporal arteritis, herpes zoster arteritis (Jpn J Geriat 22: 110-115, 1985) 
くシンポジゥム：特異な原因による老年者の脸卒中＞

\section{5. 代謝性脳症}

\section{下条 貞友}

＜要 約> 代謝性脳症とは中枢神経系 (CNS) の一次的障害によるものでなく，全身性疾患あるいは 特定臓器障害に基づく二次性, 続発性のびまん性 CNS 機能不全と定義される.

これらの病態には心肺機能不全による anoxia，水電解質異常，肝性脳症，尿毒症性脳症，糖尿病性 ketoacidosis, 内分泌異常等の内科領域のあらゆるものが包括される. CNS 障害の多くは異常な蓄積物 質による代謝サイクルの乱れが原因となる。

老年者は既に生理的加齢現象として存在する臟器障害, 予備能の低下のため代謝性脳症を発現し易い。 さらに意識障害や局所徵候を呈することによりしばしば脳卒中との鑑別が問題となる．老年者では加齢 とともに脳血流と脳代謝の軽度低下を来すことが知られる。これまでの代謝性脳症にかんする知見で, 脳酸素消費量の低下にかかわらず脳血流が正常もしくは高值に維持される。いわゆる代謝・血流解離現 象が確められている. 生理的条件下では一般にこの解離現象は存在せず，局所の血流・代謝は神経機能 とパラレルに動く, 従って老年者のごとく脳血管のびまん性もしくは局所的狭窄に基づく脳血流障害が 潜在する状態では, 代謝性脳症を来す基礎病態が加わると CNS 細胞機能維持に著しく不利な要件が発 生する。すなわち局所の血流のカップリング調節にかんする homeostasis の低下から脳機能障害は不可 逆性の経過をたどる。たと学ば non-ketotic hyperosmolar coma with hyperglycemia は老年者代謝性 脳症の特異性を示す代表的なものである。すなわち意識障害，ミオクロヌス，その他不定の精神症状， 局所徵候を呈し mortality も高く, $1 / 3$ の症例が当初脳卒中と誤られる。この homeostasis の欠陷は, 治 療面でも重要で, 急激な水・電解質補正が低ナトリウム血症に橋中心性髄鞘崩壊症のごとき重篤な合併 症を来すと報告されている，以上老年者代謝性脳症の診断と治療上の特異性について述べ，各代表例の 問題点を概述した。

Key words : 代謝性脳症, 水・電解質異常, 臓器障害, 老年者, 予備能低下

老年者は既に生理的に存在する臓器障害, 予備能の 低下のため代謝性脳症を合併し易く，ときにそれが局 所徴候を呈するために脳卒中との鑑別が問題となる。 したがって診断掞よび治療上, 代謝性脳症の本態を理 解することは重要と思われる。

\section{I. 代謝性脳症 Metabolic encephalopathy とは?}

中枢神経系の一次的障害によるものでなく，全身性 疾患, あるいは特定臓器の障害を基盤として二次性・ 続発性に中枢神経系の機能不全を来した病態を総称す る.この背景となる代謝性病態として循環器・呼吸器 障害による脳のアノキシア, 電解質拉よび体液の渗透 圧異常, 肝性脳症, 尿毒症性脳症, 肺性脳症, さらに 糖尿症性ケトアシドーシス, 低血糖, 高乳酸血症を含 めた糖代謝異常, 内分泌異常に由来する疾患群等を広

S. Shimoje：東京慈恵会医科大学第 2 内科
く包括する。

これらの中枢神経系障害の成因の多くは異常な蓄積 物質による酸・塩基平衡障害, 酵素・補酵素機能不全 に基づく代謝サイクルの乱れ，Na-K pump の異常に よる細胞機能不全等があるが，各種の異常の複合され た病態も少なからず存在する。

広義の代謝性脳症に含まれるものに, 内因性に対す る外因性といら語が用いられる。内因性という語が狭 義に解釈されれば前述の病態を限定することになるの に反し, 外因性は薬剤, アルコール, 麻薬等に基づく ものをいう。

\section{II. 代謝性脳症の頻度}

Plum \& Posner の報告によれば，広義の代謝性脳 症, すなわち内因性・外因性を含めたものが, 診断不 明で入院し後に原因を解明し得た昏睡患者500例のう ち326例（65.2\%）であったといら ${ }^{1}$ (表 1)。これを狭 
Table 1 Final diagnosis of "coma of unknown etiology" -500 Cases-

(Plum, F. \& Posner, J.B 1980)

\begin{tabular}{l|r|r}
\hline & No. & (\%) \\
\hline I Metabolic and diffuse cerebral & 326 & $(65.2)$ \\
$\begin{array}{l}\text { disorders } \\
\text { Endogenous toxins and } \\
\text { deficiency }\end{array}$ & 63 & $(12.6)$ \\
$\quad$ Hepatic encephalopathy & 17 & \\
$\begin{array}{l}\text { Endocrine, electrolytes } \\
\text { acid-base disorders }\end{array}$ & 12 & \\
Hyper or hypothermia & 9 & \\
Uremia \& dialysis & 8 & \\
encephalopathy & 3 & \\
$\begin{array}{l}\text { Pulmonary encephalopathy } \\
\text { Others }\end{array}$ & 14 & \\
\hline
\end{tabular}

義のものすなわち内因性に限定すると63例（12.6\%） となり, 頻度の高いものから肝性昏睡, 内分泌性, 電 解質, 酸塩基平衡異常, 尿毒症, 透析脳症の順であっ た。この成績では年齢因子について分析がなされてい ないが，電解質異常，非ケトン性高血糖性高渗透圧血 症, 肝性, 肺性脳症等は老年者に多いことが知られる. このような分類は医療施設の社会的環境，背景人口， 専門とする領域によって著しく異ると思われるが，代 謝性脳症が意識障害症例の約半数を占める事実は興味 深い.

\section{III. 代謝性脳症各論}

（1）尿毒症性脳症

腎不全に由来する高窒毒血症をはじめ，様々の蓄積 性物質の存在，代謝性アシドーシスで知られる，近年 メチルグアニジン等のグアニジン化合物いわゆる uremic toxins が中枢神経系障害の原因物質として注 目されている ${ }^{2)}$. しかし最近透析治療の早期開始, 透析 方法の改善により典型的脳症をみることはむしろ稀と なっている ${ }^{3) ~ 5)}$ ，脳症の 1 つの指標である脳波異常の 発現率も減少傾向にあり，脳波の重症度分類でも軽度 のものが多い。しかし若年例に比し 50 ６0歳以降の症 例では高度異常脳波, 透析に伴う不均衡症候群, 透析 脳症の発現が高いことが知られている677.

われわれは透析施行中の尿毒症患者で脳症を臨床的 に認めない 41 症例に聴性脳幹反応を行って検討したと ころ $15 \%$ に潜時の異常を認めた ${ }^{8)}$ 。さらに非透析例で 腎不全期間も I, III, V 波各潜時に有意の相関を示す延 長をみた。この所見が，潜在性の代謝性脳症を示すか 否かは明らかでないが，脳波異常とともにその可能性
を示唆する。透析脳症も aluminum との関連が最近欧 米で注目されている特殊な病態である ${ }^{9}$. 進行性の痴 呆とともにミオクローヌス, 言語障害, 運動性失語, 痓挛等の多彩な精神・神経徵候を呈する。本邦での集 計によれば 30 症例の平均年齢は 56.3 歳で 2 年以内の死 亡率は $58 \%$ であった。

(2) 高アンモニア血症と肝脳疾患

肝性昏睡も代謝性脳症の代表的なものの 1 つであ る. 高アンモニア血症, 高 $\alpha$-ケトグルタラメート血症, 羽ばたき様振戦, 脳波上の 3 相波を認めれば診断は確 定する。皇発症様式が突発性で頭頂葉症候に類似 するため脳卒中発作と誤られることがある。

[症例 1]56歳女性. 歩行障害, 構語障害, 手振の 振戦（非定型的はばたき振戦）を主訴として入院. 反 復して扣こる意識障害等から当初 TIA と診断した。 し かし高アンモニア血症の存在により肝性脳症，とくに shunt encephalopathy を疑い腹腔動脈撮影，右腎静脈 選択的採血によるアンモニウムの最高值を確認後, shunt 結毞術を施行し全治せしめた。肝性昏睡の初発 症状がしばしば脳卒中発作に類似する突発性, 間欠性 であることは留意すべき点である。

（3）水・電解質異常

老年者に招いては経口摄取不足，下㢉，呕吐，感染 等による水電解質喪失を引き金としてしばしば高渗透 圧血症を来す。

(i ) 高渗透圧血症

$$
\mathrm{mOsm} / \mathrm{kg}=2(\mathrm{Na}+\mathrm{K})+\frac{\text { glucose }}{18}+\frac{\mathrm{BUN}}{2.8}
$$

臨床上血清渗透圧值を概算するのに上の式はよく用 いられるが，最も数值に影響を及ぼすのが血糖值，尿 素窒素さらに $\mathrm{Na}$ 值であることが判る. 血糖值の上昇 に由来する高渗透圧血症として代表されるものに非ヶ トン性高血糖性, 高渗透圧性昏睡 non-ketotic hyperosmolar coma with hyperglycemia がある. 本症では 血清レベルの深度と血清渗透圧の間にはパラレルな相 関がみられ，報告例の多くが比較的高齢で局所徵候を 呈するために脳卒中発作との鑑別が問題となる ${ }^{10)}$. Arieff らの報告によれば局所性㾏挛, 片麻痷, 失語等

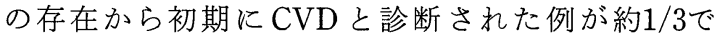
あったといら ${ }^{11)}$ 。興味ある所見として剖検例では殆ん ぞ異常所見のみられないことで意識障害や局所徵候が 中枢神経系の機能異常に基づくものであることを示唆 する。

(ii) 高 $\mathrm{Na}$ 血症 


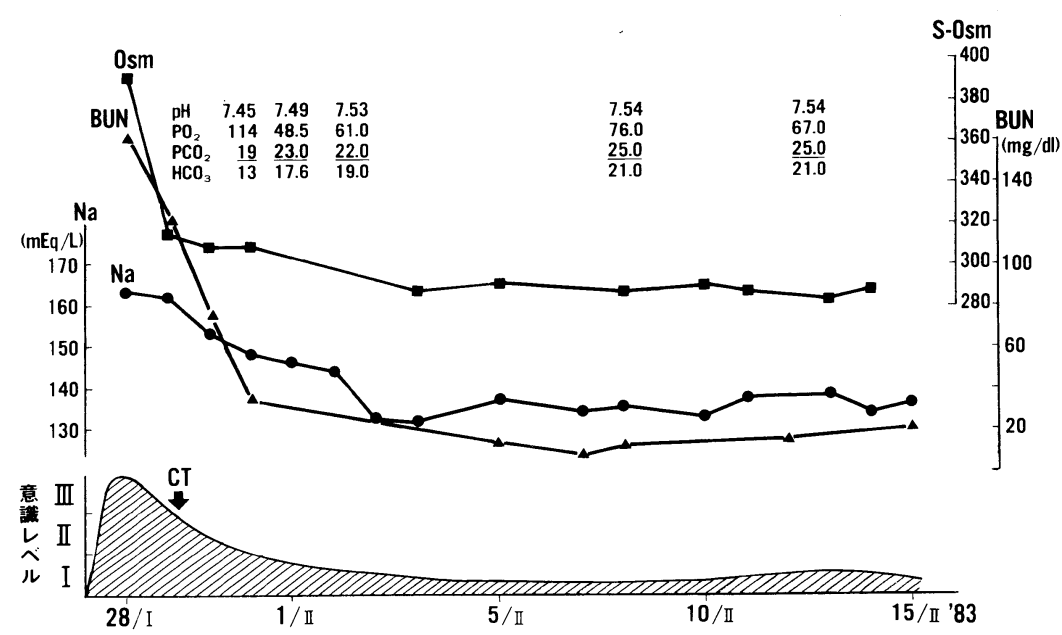

Fig. 1 S.K. 82 year-old. M. Senile Dementia

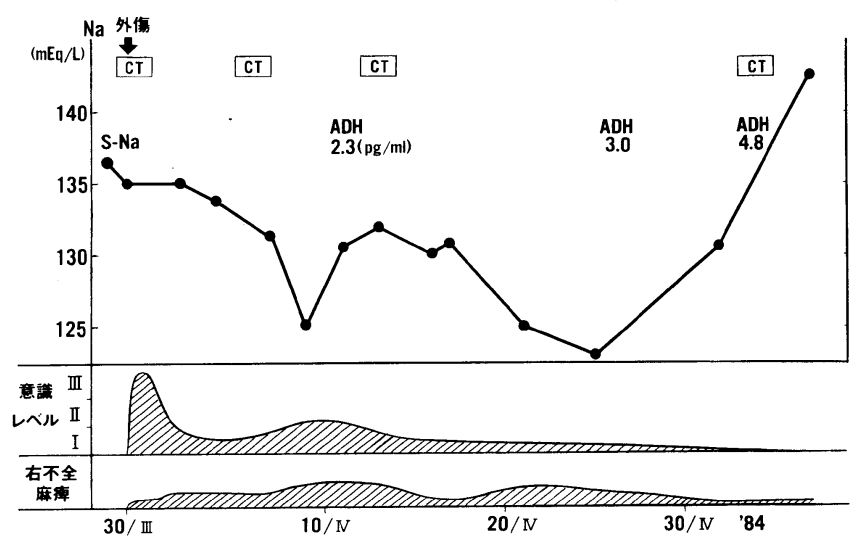

Fig. 2 S.T. 84 year-old. M. Subdural Hematoma

高 $\mathrm{Na}$ 血症と高窒素血症を伴い意識障害を来した症 例を呈示する。

〔症例 2〕82歳男性. 老年痴呆が 7 年前より存在し 進行性の経過であった（Fig. 1). 感染を引き金として 単純脱水を来し，血清 $\mathrm{Na} 160 \mathrm{mEq} / l$ 血清渗透圧 400 $\mathrm{mOsm} / \mathrm{kg} \mathrm{H} \mathrm{H}_{2} \mathrm{O}$ を呈した。このため低張液による急激 な補液を行ったところ意識障害はかえって悪化をみ た. CTでは老年痴呆に特有の脳溝の開大, 脳萎縮の所 見がみられず，びまん性の脳浮腫が存在すると考えら れた。本例は，その後の経過で適切な補液，脳浮腫対 策により意識レベルは改善したが, 高 $\mathrm{Na}$ 血症, 高渗透 圧血症に対する急激な補正がしばしば医原性に脳浮腫 を来したよい例証かと思われる，血糖值の補正と同様 に血液渗透圧を急激に低下させると髄液渗透圧の低下
が遅れ相対的に血液・髄液間の渗透圧勾配を生じて水 の頭蓋腔内移動が括こり脳浮腫が増悪する ${ }^{12) 13)}$ 。

(iii) 低 $\mathrm{Na}$ 血症

種々な原因による低 $\mathrm{Na}$ 血症も高龄者の日常臨床に しばしば遭遇する病態である。

〔症例 3 〕頭部外傷後に低 $\mathrm{Na}$ 血症のため意識障害, 神経症状の遷延した症例を呈示する。84歳男性.ベッ トより転落し脳内血腫を生じ保存的治療を行っていた ところ, 低 $\mathrm{Na}$ 血症が発現し同時に意識レベル, 右不全 麻痺の悪化をみた。電解質補正とともにこれらは改善 したが, 少なくとも治癒過程を遷延させたと思われる。

最近急激な低 $\mathrm{Na}$ 血症の補正後に生じる橋中心髄鞘 崩壊症 central pontine myelinlysis (CPM) が多数報 告されるようになったが, Laurenoらは実験的に雑種 


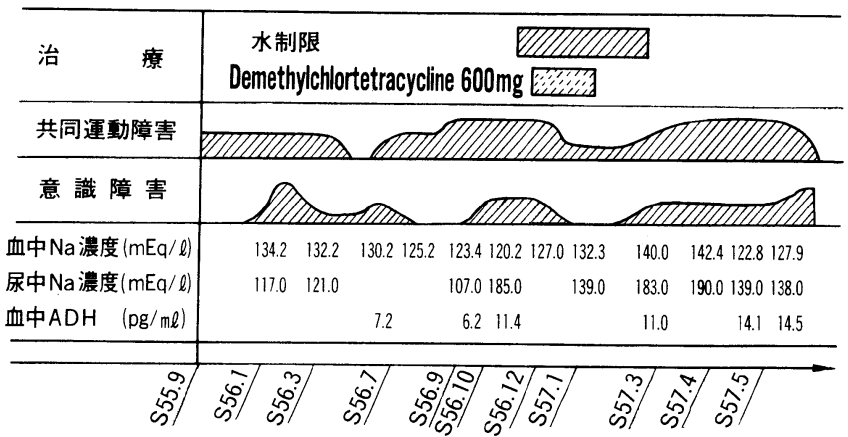

Fig. 3 ISADH 64歳, 男性

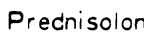

$6 \mathrm{MP}$

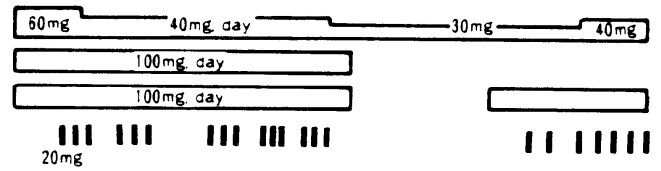

Daunomycin

Furosemide 1000mg.cay

Salmon C.T

Ca-- free HO
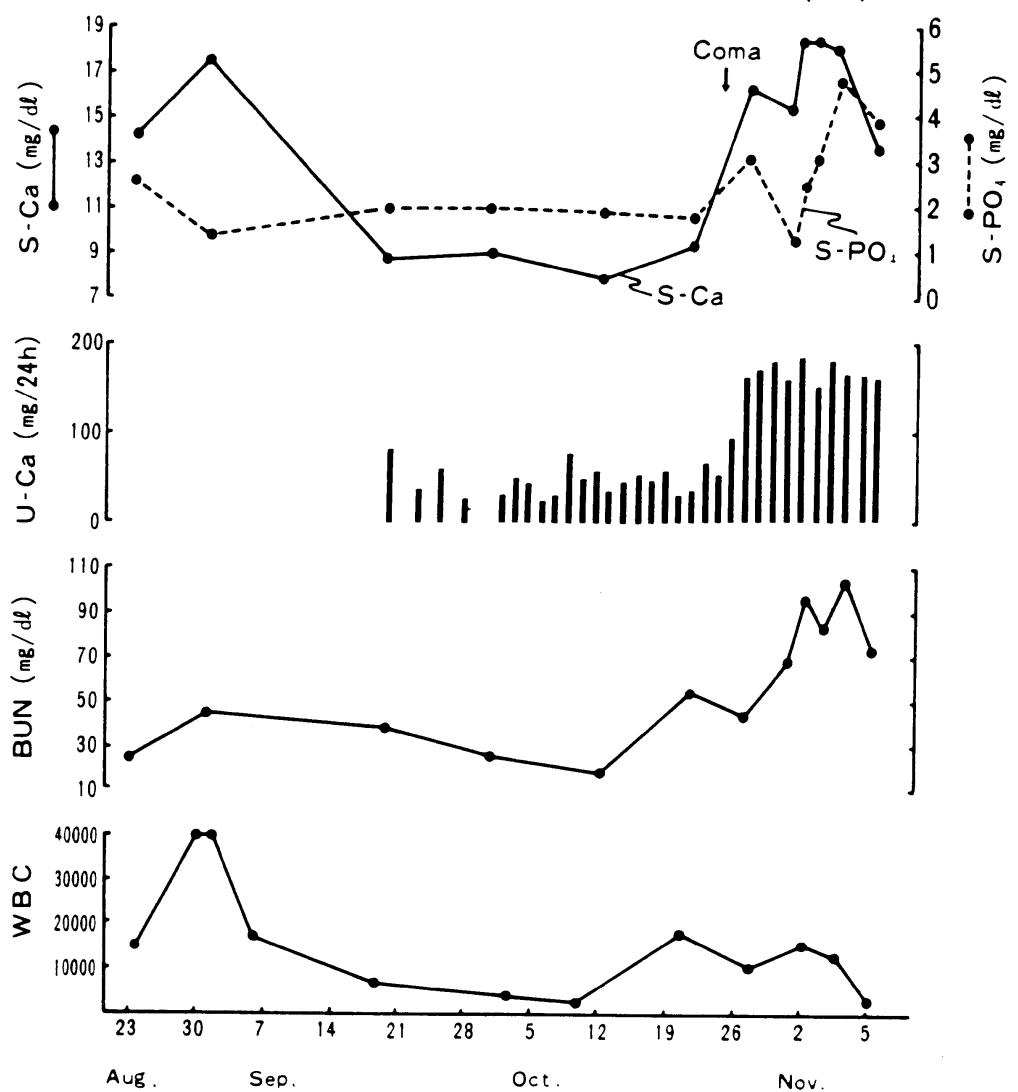

Fig. 4 
犬を用いてこれを実証した。すなわち少なくとも4 日 間以上持続した低 $\mathrm{Na}$ 血症を食塩水で補正した10例中 5 例に病理所見を認めた ${ }^{14)}$. Norenberg らもラットの 実験で追試した結果同様の所見を得, 補正前の低 $\mathrm{Na}$ 血症の持続期間が最も重要な因子であると述べてい $る^{15)}$.

以上の事実より持続期間の不明な低 $\mathrm{Na}$ 血症の補正 は緩徐に行ら必要があると思われる。

(iv) SIADH (Syndrome of inappropriate secretion of $\mathrm{ADH}$ ) SIADHもまた低 $\mathrm{Na}$ 血症を来し意識 障害の原因となる病態である。

〔症例 4〕64歳男性（Fig. 3)。本例は初発症状が失 調性歩行, 左側の共同運動運動障害, CT に所見なく脳 血管撮影で椎骨脳底動脈系の高度な硬化所見を認めた ため, 当初 CVD と診断した。 しかし発症 4 力月頃より 意識障害が発現, 低 $\mathrm{Na}$ 血症. 尿中 $\mathrm{Na}$ 排泄増加, 水負 荷試験, DPH 負荷試験等より確定診断した。この頃よ り胸部レ線上腫瘍陰影を認め X 線照射にも反応せず, 全経過約 1 年 8 力月で死亡した。剖検で左下葉主気管 支基部に $10 \times 6 \times 4 \mathrm{~cm}$ 大の腫瘤が認められ組織学的に は末分化の燕麦細胞癌であった。腫瘍組織切片につい ての生化学的検索では $4,916 \mathrm{pg} / \mathrm{g}$ の高濃度 ADH を検 出. ADH 産生腫瘍であったことが判明した。

(v) 高 $\mathrm{Ca}$ 血症

腫瘍年齢にある老年者では骨転移，多発性骨髄腫白 血病，リンパ腫等の骨浸潤等によって高 $\mathrm{Ca}$ 性意識障 害を来す ${ }^{16)}$ ．副甲状腺機能六進症によるものもよく知 られた病態である1718)。

〔症例 5〕（Fig. 4)，67歳男性, 急性リンパ性白血病 の診断で治療中, 血清 $\mathrm{Ca}$ が $17.4 \mathrm{mg} / \mathrm{d} l$ と高值を来し 抗腫瘍剂，プレドニソロン投与により正常域まで低下 した。しかし白血病の再燃とともに血清 Ca は急激に 上昇，意識レベルは深昏睡になで低下した。腎不全の 合併もあり Ca free の透析液により血液透析治療を 行ったが死亡, 剖検により腫痬細胞の骨浸潤を確認し た.

〔症例 6〕76歳男性, 下咽頭腫瘍, (組織学的に扁平 上皮癌) に対し放射線治療を施行中，血清 Ca $13.8 \mathrm{mg} /$ $\mathrm{d} l$ を呈し, 意識障害, 精神症状, 振戦が発現, 治療に より Ca 值が低下すると中枢神経症状にも一時的改善 がみられた。 しかし再び Ca 值が上昇, 腎不全を合併し て死亡した。本例は悪性腫瘍の骨転移によりいわゆる 高カルシウムクリーゼを呈した。一般に血清 $\mathrm{Ca}$ 值が $16 \mathrm{mg} / \mathrm{d} l$ を超光ると中枢神経症状が発現するといわ
れる. しかし低蛋白血症の存在や閾値が低い老年者に 揖いては, $12 \sim 14 \mathrm{mg} / \mathrm{d} l$ の範囲で既に症状が招来され る報告がみられ留意すべき点と思われる。

\section{IV. まとめ}

以上代表的な代謝性脳症若干例を呈示し, 鑑別診断, 治療上の問題点の概要を述べた.

老年者では既に存在する腎, 肺等を中心とする臓器 障害のため予備能に乏しく，体液ホメオスターシスの アンバランスが容易に発現する．従ってこれらの早期 発見・適切な治療が重要であるが, 低 $\mathrm{Na}$ 血症の項で述 べたごとく急激な水・電解質・渗透圧の補正は中枢神 経系に対ししばしば不利な結果を招く。

一般に老年者では脳血管の硬化による加齢現象とし て脳血流と脳代謝の軽度低下がみられる. $\mathrm{N}_{2} \mathrm{O}$ 法を初 めとする従来の代謝性脳症にかんする知見では, 代謝 の指標である脳酸素消費量の低下が認められている。 しかし脳血流量は正常もしくは逆に上昇しいわゆる $\mathrm{CBF}^{-\mathrm{CMRO}_{2}}$ uncoupling すなわち代謝と血流の解離 がみられる。生理的な条件下では代謝と血流な密接不 可離で, radioautography 法で測定した局所脳血流・ 代謝も相互にパラレルな動きを示す。

既に脳血管の局所的狭窄や閉塞のみられる老年者の 場合, 酸素の供給不足, 低血糖の侵襲や電解質異常等 の代謝性脳症の病態が加わると脳細胞機能維持に不利 な諸条件が加わり, 意識障害や局所神経症状が発現す ると考兄れる。この意味で non-ketotic hyperosmolar coma with hyperglycemia は老年者に拈ける 代謝性脳症の特異性をよく現わす病態であると考觉ら れる.すなおち不定の精神症状や局所徵候を呈するこ とが多く morbidity も高い事実である. 今後 PET scan 等を用いた局所の代謝異常の検討は老年者の代 謝性脳症の本質に迫る有力な手段と期待される。

\section{文献}

1) Plum F, Posner B: Diagnosis of stupor and coma. FA Davis Company, Philadelphia, Third Edition 1982, pp1-3.

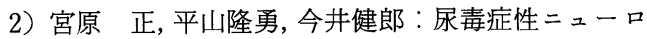
パチー患者に抢ける末梢神経の生化学的検討一と くに Guanidino 化合物について一未梢神経障害 一成因々病態一。祖父江逸郎編, 146, 永井書店, 大阪, 1982 .

3）宮原 正，宮島眞之：尿毒症性脳症.内科 51 ： 
849, 1983.

4）宮原 正, 宮島廂之：尿毒症性脳症. 臨床と研究 $55: 722,1978$.

5）宮原 正：末梢神経障害の臨床一Uremic neuropathy を中心. 慈恵医大誌 $94: 1,1979$.

6) Kennedy AC: Dialysis disequilibrium syndrome. EEG Clin Neurophysiol $29: 213$, 1970.

7) Kennedy $\mathrm{AC}$, et al: The pathogenesis and prevention of cerebral dysfunction during dialysis. Lancet 1:790, 1964.

8）宮島眞之：慢性腎不全における神経・筋障害の神 経電気生理学的検討. 慈恵医大誌 $97: 1021$, 1982.

9) Sideman $\mathrm{S}$, et al: The dialysis dementia syndrome and aluminum intoxication. Nephron $31: 1,1982$.

10) Maccario M, Messis CP, Vatola EF : Focal seizures as a manifestation of hyperglycemia without ketoacidosis. Neurology $15: 195,1965$.

11) Arieff $\mathrm{AI}$, Caroll $\mathrm{HJ}$ : Nonketotic hyperosmolar coma with hyperglycemia: Clinical features, pathophysiology, renal function, acid- base balance, plasma-cerebrospinal fluid equilibria and effects of therapy in 37 cases. Medicine (Baltimore) $51: 73,1972$.

12) Ross EJ, Christie: Hypernatremia. Medicine (Baltimore) $48: 441,1969$.

13) Arieff AI, Guisado R: Effects on the central nervous system of hypernatremia and hyponatremic states. Kidney Int $10: 104,1976$.

14) Laureno $R$ : Central pontine myelinolysis following rapid correction of hyponatremia. Ann Neurol 13:232, 1983.

15) Norenberg MD, Papendick RE: Chronicity of hyponatremia as a factor in experimental myelinolysis. Ann Neurol $15: 544,1984$.

16) Mundy GR, et al: The hypercalcemia of cancer : Clinical implications and pathogenesis. $\mathrm{N}$ Engl J Med 310 : 1718, 1984.

17) Patten BJ, Pages $M$ : Severe neurological disease associated with hyperparathyroidism. Ann Neurol 15:453, 1984.

18）相井平八郎, 亀山正邦：副甲状腺疾患と神経・筋症 候. 神経内科 $21: 199,1984$. 
Abstract

\title{
Metabolic Encephalopathy
}

\author{
Sadatomo Shimojo, M.D.
}

Metabolic encephalopathy may be defined as a diffuse dysfunction of the central nervous system (CNS) secondary to or following systemic disorders or a specific organ failure excluding primary $\mathrm{CNS}$ disorsers. In this category many of those in the fields of internal medicine are included as anoxia due to cardio-pulmonary dysfunctions, fluid-electorolytes disorders, hepatic encephalopathy, uremic encephalopathy, diabetic keto-acidosis and endocrinological disorders. Pertinent causes of CNS dysfunctions may be attributed to abnormal accumulations of intermediate metabolites or toxic substances due to abberations of metabolic cycles. The elders are prone to develope metablic encephalopathies as they already inherit organ failure and decreased reserve due to aging phenomena. When they develope a disturbance of consciousness or focal neurological signs, a differential diagnosis with cerebrovascular accident often becomes a problem to be solved. In the elders it is well known that there are slow but steady decrement of cerebral bloof flow (CBF) and cerebral metabolism. In metabolic encephalopathy previous studies have shown that while the cerebral oxygen consumption rate is uniformly decreased, CBF remains normal or conversely increase, the so called CBF-

II Department of Medicine, The Jikei University School of Medicine, 3-25-8 Nishishinbashi, Minato-ku, Tokyo metabolism un-coupling. No such phenomenon of uncoupling is observed under physiological conditions and regional $\mathrm{CBF}$-metabolism alternate in parallel with local neuronal functions. In elders in whom diffuse or local stenosis of cerebral vessels are present or latent, any complication of underlying pathology for metabolic encephalopathy may be a hazard to maintain normal CNS functions. Namely, CBF-metabolism coupling may be distorted to render an irreversible change of neuronal functions by the loss of homeostatic regulations. Non-ketotic hyperosmolar coma with hyperglycemia may be a representative example of metabolic encephalopathy in the elders since in this disorder a loss of consciousness, myoclonic jerk, mental signs and other focal abnormalities are frequent with a high mortality rate. In a reported series one third of patients were mistaken as cerebrovascular accidents on admission. This difficient homeostasis in the elders may be similarly applied to therapy of metabolic encephalopathy, as in hyponatremia central pontine necrosis has been not infrequently observed when rapid corrections of electrolytes are attempted.

Various encephalopathies are presented and discussed in terms of diagnosis and therapy specific to the underlying pathophysiology.

key words: metabolic encephalopathy, fluid-electrolytes disorder, organ damage, the elders, decreased reserve

(Jpn J Geriat 22: 116-122, 1985) 